\title{
Research Paper \\ Presenting a paradigmatic model of underlying factors result in marital infidelity based on grounded theory
}

Farzane Tamrchi ${ }^{1}$, Esmaeel Asadpoor ${ }^{2}$, Kiyanosh $_{\text {Zahrakar }}{ }^{3}$

1. Ph.D Student, Counselling Depatment, Faculty of Psychology and Educational Science, Kharazmi University, Tehran, Iran.

2. Assistant Professor, Counselling Department, Kharazmi University, Tehran, Iran.

3. Associate Professor, Dean of the Counselling Department, Kharazmi University, Tehran, Iran.

Citation: Tamrchi F, Asadpoor E, Zahrakar K. Presenting a paradigmatic model of underlying factors result in marital infidelity based on grounded theory. J of Psychological Science. 2022; 20(107): 2027-2043.

URL: https://psychologicalscience.ir/article-1-1074-fa.html
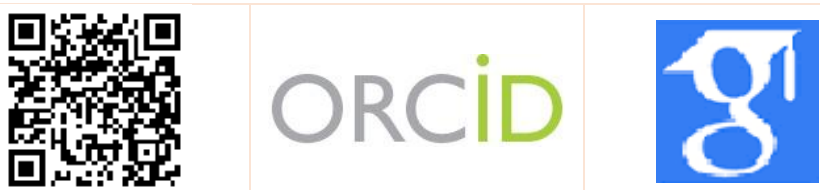

$\underline{10.52547 / J P S .20 .107 .2027}$

A R T I C L E I N F O

A B S T R A C T

Keywords:

Marital infidelity, causing effects,

men,

women
Background: Marriage is substantially recognized as a common convention to form an exclusive relationship in which emotional and sextual commitments of couples are fulfilled. Unfulfilled commitments and marital infidelity though are considered to be a thread to family and society health. Consequently, identifying causing effects of marital infidelity is highly significant to prevent it.

Aims: Current research hopes to investigate underlying factors on individuals' inclinations which lead to marital infidelity to preclude its outbreak in families.

Methods: This qualitative research is conducted on the basis of grounded theory method. Population of the study Present population involves entire men and women live in Tehran who have committed infidelity between 2017 to 2020 and have visited Ruzbeh, Rahe Now, Parand as well as Mehraeein counseling centers. Participants are purposefully chosen from eleven men and ten women who meet the requirements.

An in-depth semi-structured interview is carried out. Data analysis is performed based on Strauss and Carbine (1990) three-stage method.

Results: Data analysis in Open Coding Stage is divided into two main categories. Causal conditions (individual - personality, individual - family, husband and wife - relationship) and Texture conditions (society, occupation, cyberspace) and a subcategory including Intervening factors (friends, money, power, positive characteristics discovery) and needs category from Axial Coding Stage besides three core categories (predisposing factors, deterrent, responsive) are obtained. Conclusion: Infidel men and women are affected by the aforementioned main and secondary effects revolving around needs are getting into adultery. Applying practical strategies, for some it leads to positive effects such as embedment and for some others it results in impractical strategies like divorce.
Received: 08 Dec 2020

Accepted: 25 Jan 2021

Available: 21 Jan 2022

* Corresponding Author: Esmaeel Asadpoor, Assistant Professor, Counselling Department, Kharazmi University, Tehran, Iran.

E-mail: dr.iasadpour@khu.ac.ir

Tel: (+98) 9126403230

2476-5740/ @ 2021 The Authors. This is an open access article under the CC BY-NC-ND license

(https://creativecommons.org/licenses/by-nc/4.0/). 


\section{Extended Abstract}

\section{Introduction}

Marriage as the foundation of the social institution of the family has permanently existed in various societies in multifarious manifestations and has influenced different aspects (Vimalansa,2016).

However, today, the sanctity and godliness of this contract is gradually faded (Sassler \& Leitcher 2020, quoting Carlswelll Wair 2014). The commitment of exclusiveness in sexual and emotional relationships of couples are not fulfilled and this leads to marital infidelity (Allendorf \& Chimir 2013, Kargar, Kimiaee, Mashhadi 2014) which leaves huge destructive effects on mutual life of couples including impaired mental health, emotional and behavioral balance of the spouse (Wechler \& Pieerce 2020) increased risk of sexually transmitted disease (Ludova, Janice, Howiger 2013) emotional trauma and even death (Jones, Alderbek \& Figorvdo 2011) and divorce and its side-effects on children and couples. According to Kalhor (2007) the highest number of domestic homicides in Iran is related to women who have been murdered by their husbands due to illicit relationships and suspicions. On the other hand, $22 \%$ of domestic homicides is related to men who have been murdered by their wives in which $40 \%$ of the murders are done with the complicity of the wife and her lover. Despite the great body of research which has been conducted in Iran and other countries regarding the marital infidelity which is comprehensively explained in this article less research has been done to discover the underlying and fundamental reasons result in marital infidelity originating from the data collected from couples who have committed adultery themselves. All qualitative research so far is conducted phenomenologically not on the basis of grounded theory. Additionally, due to several causing effects lead to marital infidelity as well as the emergence of diverse forms of adultery there still are many unknown underlying factors which require designing a paradigmatic model that explains not only the effects but also the links between them and how they are affected by each other.

\section{Method}

This qualitative research is conducted on the basis of grounded theory. The population is provided through objective sampling and to determine the size of the samples data saturation method is used. Present population involves entire men and women live in Tehran who have committed infidelity between 2017 to 2020 and have visited Ruzbeh, Rahe Now, Parand as well as Mehraeein counseling centers. Participants are purposefully chosen from eleven men and ten women who meet the requirements.

The data is analyzed using three-stage constant coding method proposed by Strauss and Corbine (1990) which includes open coding stage and axial coding stage. For the sake validity and reliability of the research data, Cuba and Lincoln (1994), quoted by Bryman (2001) four-indicator creditability is applied. Considering the objective of current paper which is establishing a paradigmatic model showing the underlying factors which create the tendency towards marital infidelity and how they are linked together, three-stage coding method then is considered to the best possible method.

\section{Results}

Data collected from the participants of this study shows that the tendency to establish extramarital relationships is affected by a body of interactive effects in different individuals out of which the "needs" factor is considered as the central category among all the causing effects of the marital infidelity. This factor on one hand includes distinct needs and on the other hand is integrated with other circumstances and causes. Other causes involve present situation affecting marital infidelity which itself is divided into two categories of individualpersonality and relationship. Individual traits including dependent characters, Dark Traid and lover. Relationship factor is divided into three categories containing pre-marital, during-marriage and postmarital effects which are influenced by the intervening conditions such as positive characteristics discovery, friends' influence, money, power and other core and contextual conditions such as wrongly set examples in the society, working situation, nonobservance of communication boundaries in 
workplace, poor economic conditions and cyberspace which in turn facilitates the access and increases the tendency towards extramarital relationships to fulfill the unfulfilled needs. These needs are categorized into five parameters including emotional, sexual, thrills, dignity, respect and power.

Table 1. Fundamental effects, concepts, categories, classes influencing the inclination towards infidelity

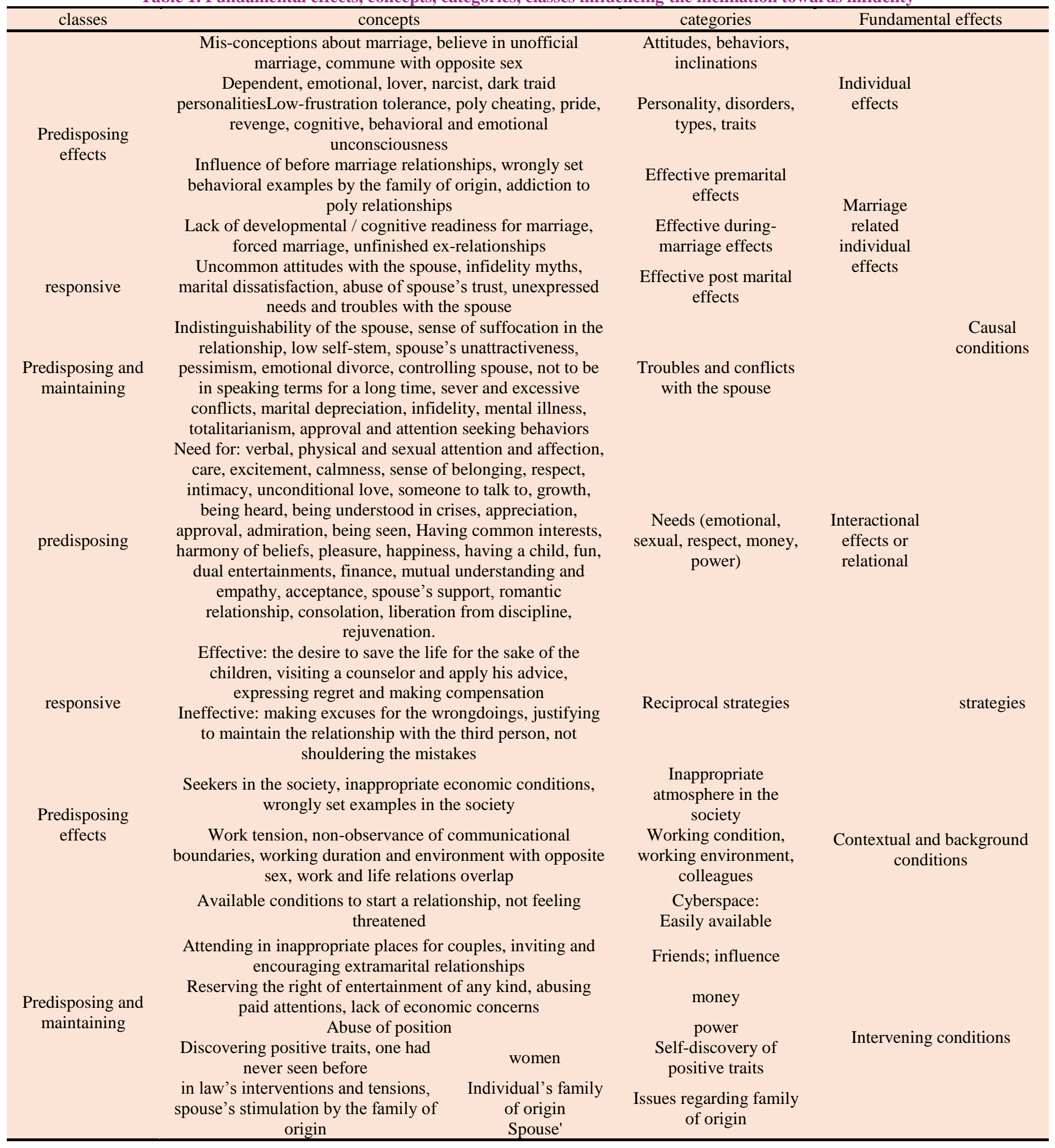




\begin{tabular}{|c|c|c|c|}
\hline classes & concepts & categories & Fundamental effects \\
\hline responsive & $\begin{array}{l}\text { Positive consequences: spouse's decision to compensate for } \\
\text { the weaknesses, increased tolerance against marital conflicts } \\
\text { which lead to maintaining a sick home life }\end{array}$ & Positive and negative & consequences \\
\hline
\end{tabular}

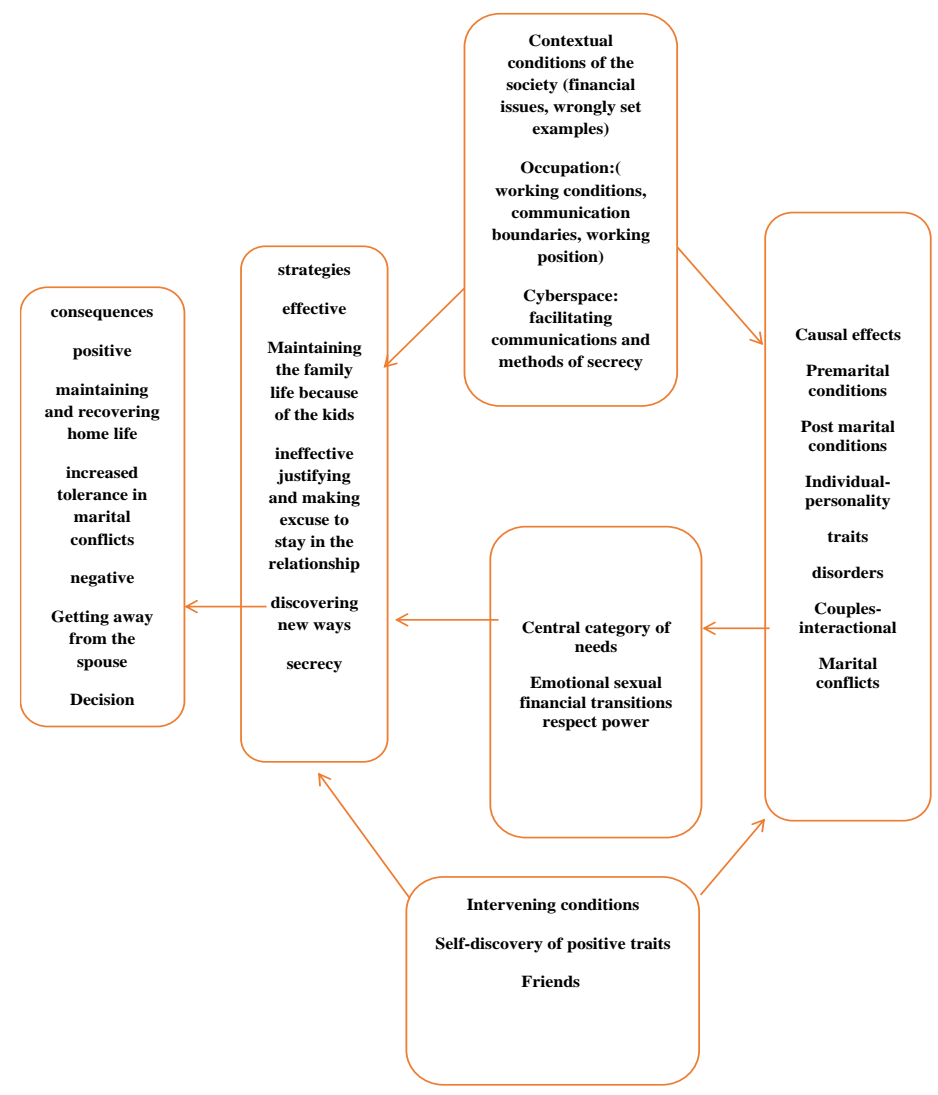

Figure 1. The paradigm of the underlying factors of marital infidelity

Table 2. Demographic characteristics of the participants in the study

\begin{tabular}{|c|c|c|c|c|c|c|c|c|}
\hline Age & $\begin{array}{l}\text { Marriage } \\
\text { age }\end{array}$ & $\begin{array}{l}\text { Age of } \\
\text { starting the } \\
\text { relationship }\end{array}$ & $\begin{array}{l}\text { Duration of the } \\
\text { relationship }\end{array}$ & $\begin{array}{l}\text { Type of the } \\
\text { relationship }\end{array}$ & Education & Occupation & Children & $\begin{array}{l}\text { Number of the } \\
\text { relationships }\end{array}$ \\
\hline
\end{tabular}

\section{Conclusion}

The aim of current study is to identify underlying factors of marital infidelity in men and women in order to establish a model to educate its prevention. Review of the background studies shows that Jane Foron (2014), Mafasana Motadora and Nemymaro (2017) stress that emotional needs are in line with the findings of the current study. Furthermore, in Ejtehadi and Vahedi (2017), Choupani et al. (2016), Dimiter (2016) and Hoseinzadegan (2017) studies individualpersonality causal conditions are consistent with the results of this paper. Also, research conducted by Fathi, Fekrizade and Bolhari about causal and contextual conditions, historical context and the circumferential effects and cultural contexts are in congruence with the findings of this study. Moreover, Peykanian and Farhadi (2017), Rustaee (2016) and Ajam (2016) studies about cyberspace are consistent with the results of this article. Concerning the intervening conditions Dimiter's research (2016) is pursuant to the current study findings. Consequently, comparing the results of this study with previous studies it is clear that not a single factor is involved in creation of the tendency towards marital infidelity but there are several interactive factors revolving around a central category and act upon them. Accordingly, a paradigmatic model is illustrated to show how infidelity is planned and continued and what the 
consequences are. The presented model is designed to avoid marital infidelity in families and wishes to contribute family counselors and therapists in educating couples.

\section{Ethical Considerations}

Compliance with ethical guidelines: The author extracted this article from the Ph.D dissertation of the first author which was approved on 06.10.2017 in the Faculty of Psychology and Educational Science, Kharazmi University, Tehran.

Funding: The present research is conducted as a Ph.D dissertation with no financial support.
Authors' contribution: The first author is the main writer of the current article. The second author is the supervisor and the third author is the advisor of the dissertation.

Conflict of interest: The author declare no conflict of interest for this research.

Acknowledgments: I would like to express my sincere gratitude to my dear supervisor and advisor and all the interviewees who kindly have participated in this research. My special appreciation also goes to the manger of Mehraeein clinic who provided a suitable atmosphere for the interviews. 


\title{
ارائه مدل بارادايمى از عوامل زمينه ساز خيانت زناشويى (مطالعه نظريه زمينهاى)
}

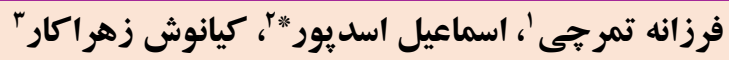

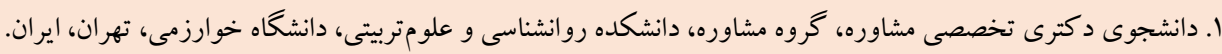

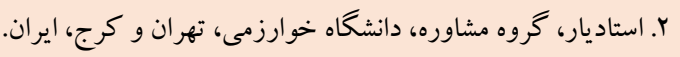

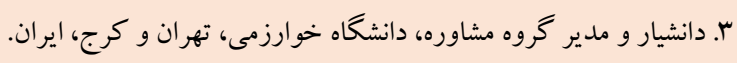

زمينه: ازدواج يكك رسم معمول و عرف براى تشكيل رابطهاى در تعهد انحصار عاطفى و جنسى بين زوج است. در حالى كه امروزه در موارد بسيارى، شاهد آسيب ديدن سلامت خانو اده و جامعه، با شكسته شدن اين تعهد و رخد دادن خيانت زناشويى هستيم. لذا شناسايى عميق عوامل

$$
\text { سبب ساز اين بديده، جهت ييشخيرى، امرى ضرورى است. }
$$

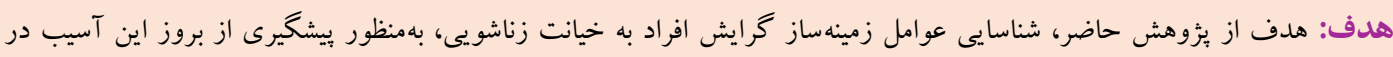

$$
\text { خانو ادهها است. }
$$

مشخصات مقاله

كليدوازه内ها:

خيانتزناشويى،

عو امل زمينهساز،

مردان،

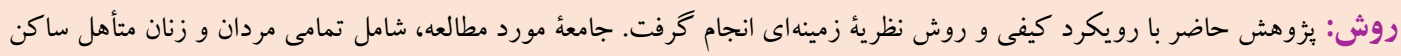

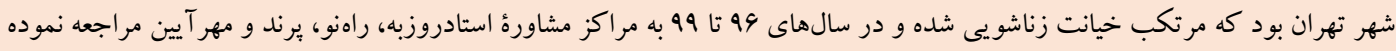

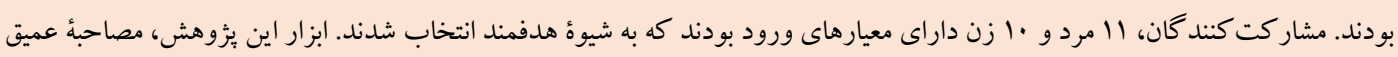

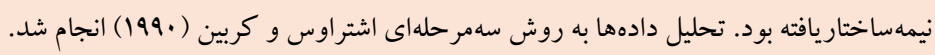

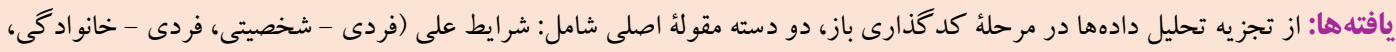

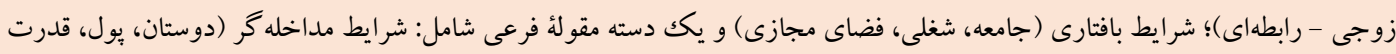

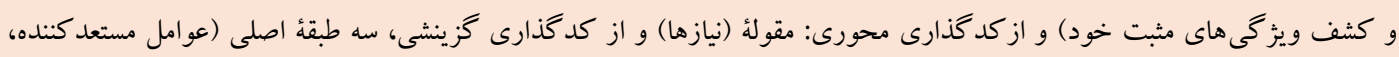
نخهـارنده و باسخ دهنده) حاصل شد. نتيجه كيرى: زنان و مردان خيانت كار، تحت تأثير مقولات اصلى و فرعى ذكرشده، حول محور نيازها، به خيانت زناشويى كرايش بيدا

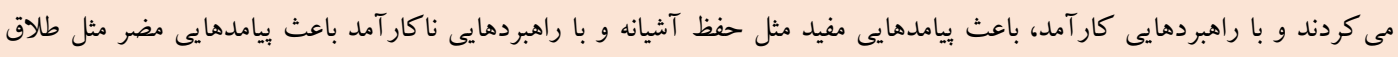

* نويسنده مسئول: اسماعيل اسديور، دكترى تخصصى مشاوره خانو اده، استاديار، گروه مشاوره، دانشكاه خوارزمى، تهران و كرج، ايران. رايانامه: dr.iasadpour@khu.ac.ir 
طى مصاحبه با f زن مرتكب خيانت زناشويى، بيان كردند كه زنان

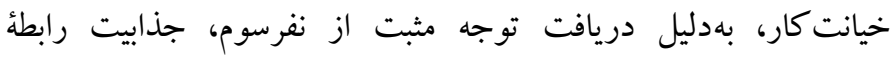
فرازناشويى برايشان بيشتر مىشده است. افشارى كاشانيان، زهراكار،

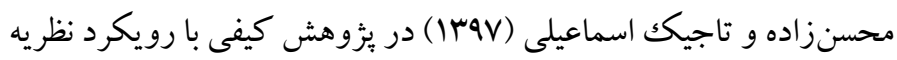

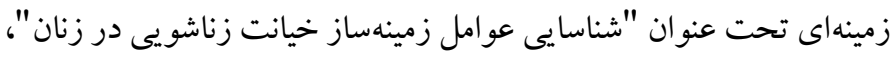
طى مصاحبه با IV زن مرتكب خيانت زناشويى، علل زمينهساز خيانت

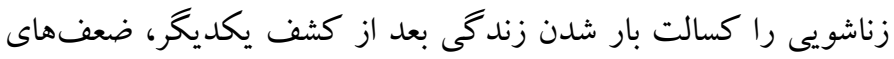

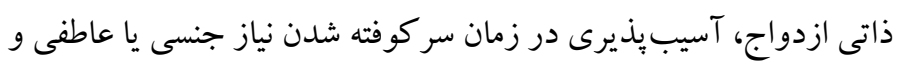

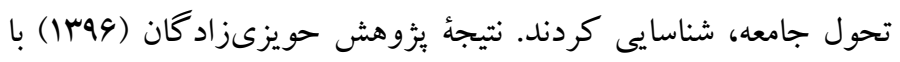

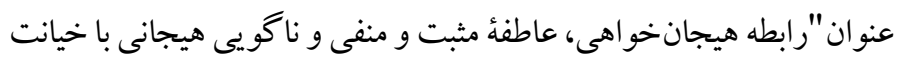

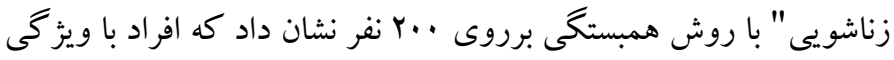

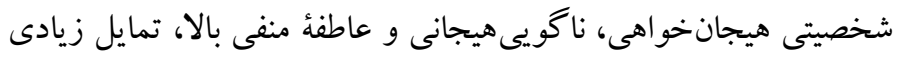

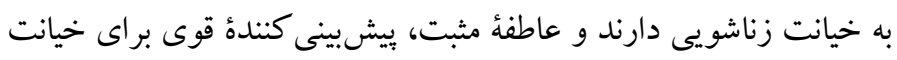

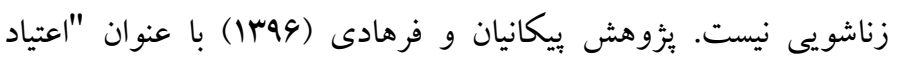

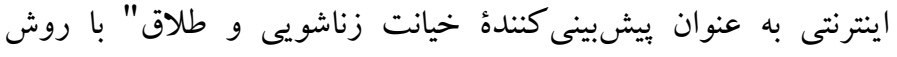

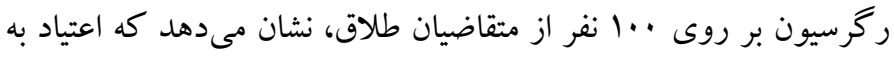

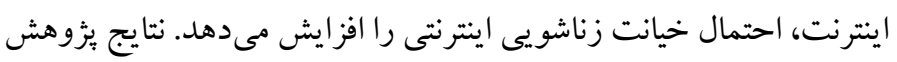

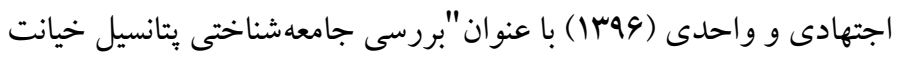

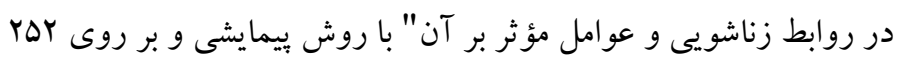

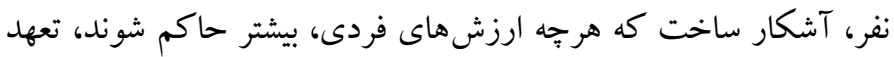

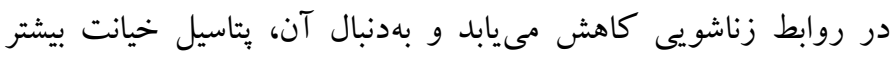

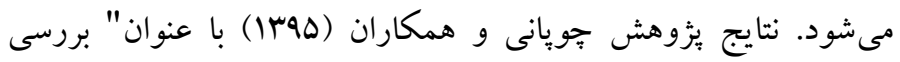

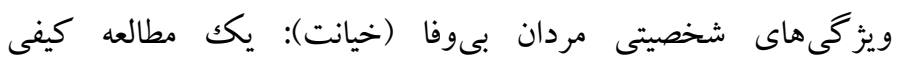

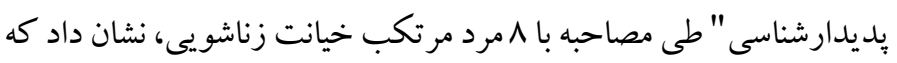
در آنها 9 ويزگ

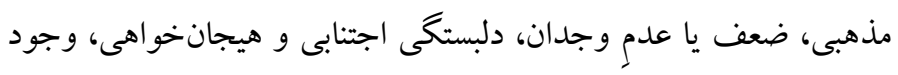

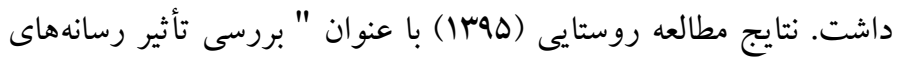

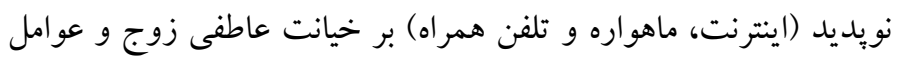

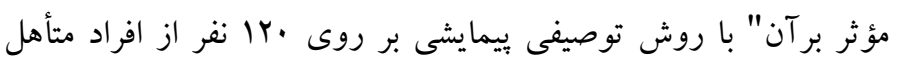

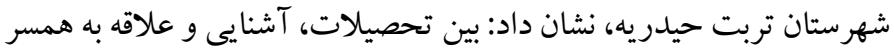
قبل از ازدواج، با خيانت عاطفى، رابطةٌ منفى وجود دارد. همجنين استفاده

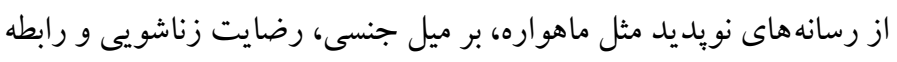

مقام

ازدواج بهعنوان اساس نهاد اجتماعى خانواده، در جوامع مختلف، اشكال

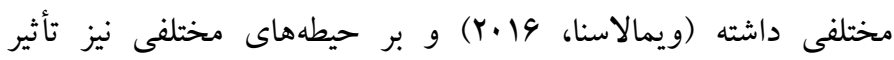

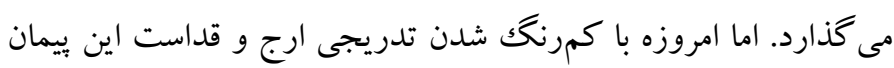

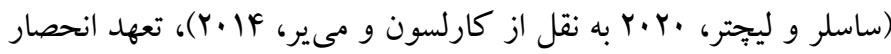
روابط جنسى و عاطفى زوج، درهم شكسته و خيانت زناشويى رخ مى دهد

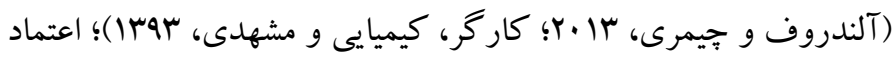

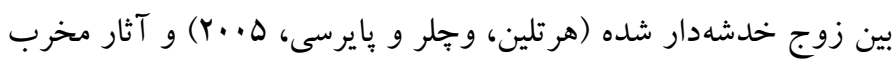
عظيمى بر زندگى مشترك زوج، مثل مختل شدن سلامتروانى و وتعادل

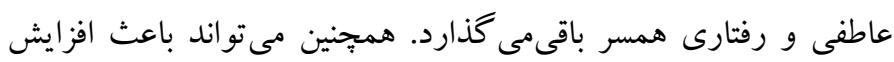

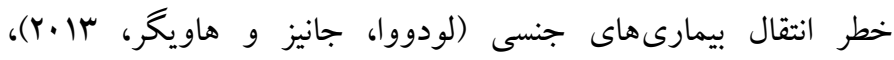
آسيب هاى عاطفى و حتى مرگك بشود (جونز، الدربك و فيكوردو، 11 (Y).

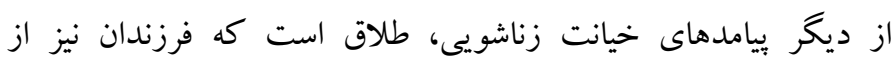

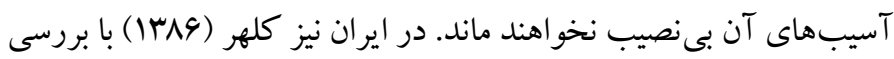

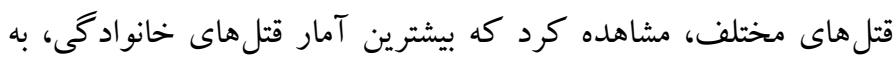
زنانى مربوط است كه به دليل رابطةٌ نامشروع و سوءظن، توسط همسران

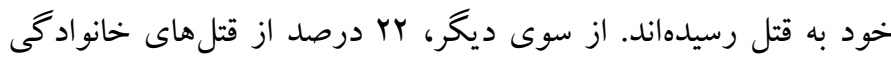

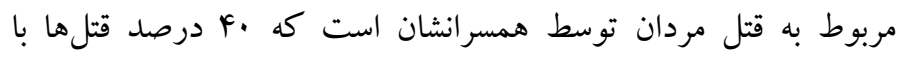
همدستى همسر با معشوق خود بوده است.

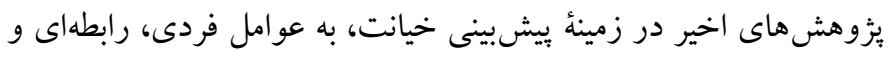

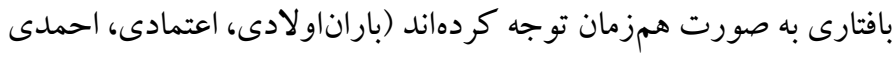

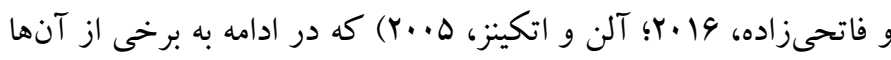

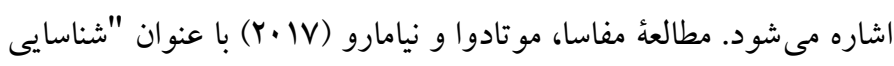

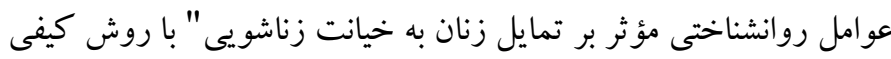

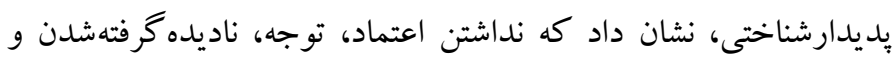
لذت نبردن از رابطه جنسى، از مهم ترين عوامل روانشناختى مؤثر در تمايل

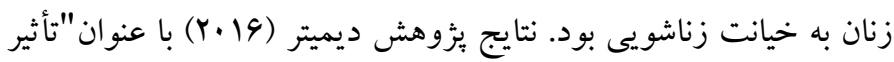

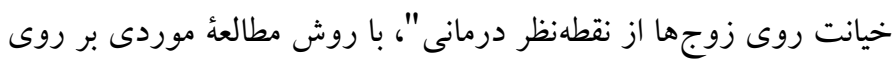

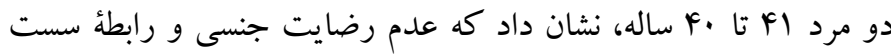
عاطفى همسران، بعد از ايجاد عدم تعادل در رابطة همسران، موجب بروز خيانت مىشوند. جين فرو و همكارانش (Y.|F) در ئزوهش كيفى

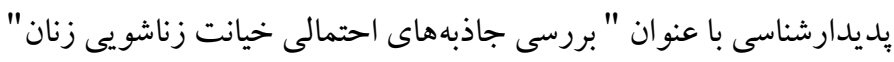


كليدى بوده است كه جه عواملى در مردان و زنان، زمينهساز گُرايش آنان به سوى خيانت زناشويى است؟

روش

الف) طرح هُووهش و شر كت كنند كان: يزّوهش حاضر با رويكرد كيفى

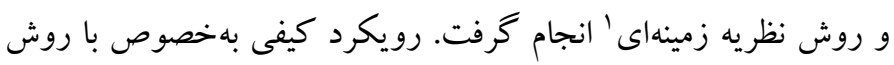

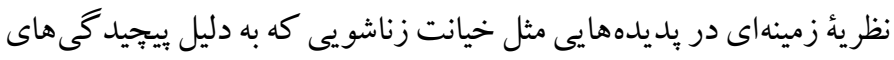
نهفته در رويدادهاى مختلف زناشويى، همواره در آن زمينه، كمبود اطلاعات همه جانبه وجود دارد، مى تواند مناسبترين روش مطالعه باشد. زيرا علاوه بر استخراج اطلاعات از دل داههاى حاصل از تجربه

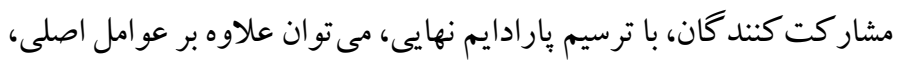

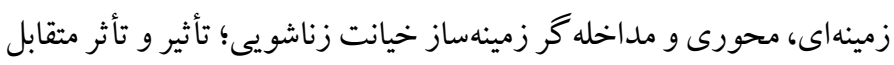

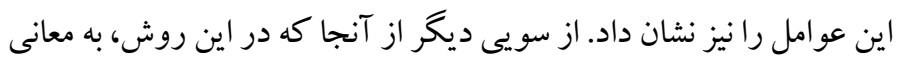

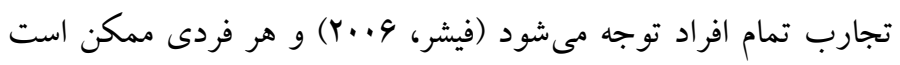
تجارب منحصر به فردى داشته باشد؛ بنابراين هر مطالعهُ نظريه زمينهاى

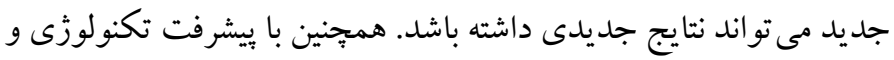

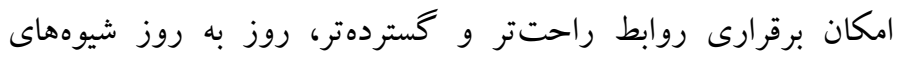

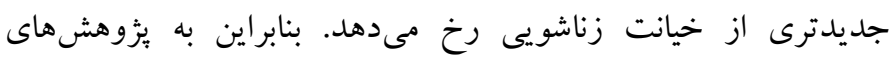
جديدترى با رويكرد كيفى و روش نظرية زمينهاى براى مطالعه و توجيه

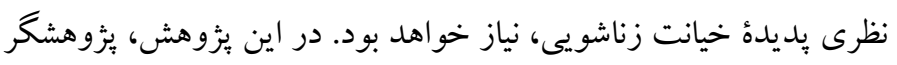

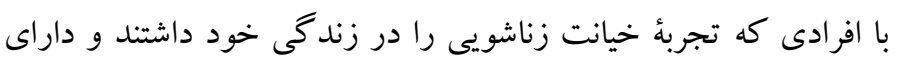
معيارهاى ورود بودند و مى تو انستند بهترين اطلاعات را در مورد موضوع ارائه دهند، مصاحبه انجام، ضبط و يادداشت بردارى نمود و در فر آيند كار نيز بر توصيف آنجه كه افراد بيان مى كنند، تمركز شد تا ديد كاههاى تازهاى

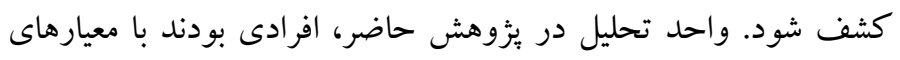
ورود زير: 1. تعدادى مرد و زن متاهل شرعى و قانونى كه در زمان خيانت، عقد دائم

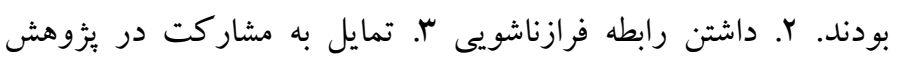

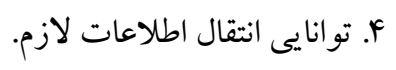

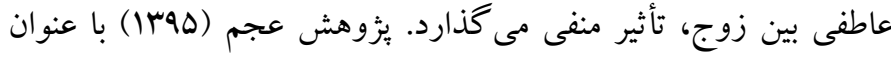

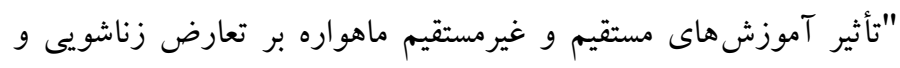

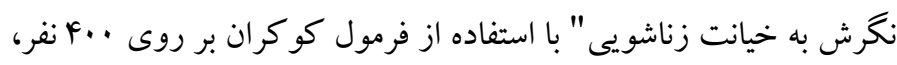

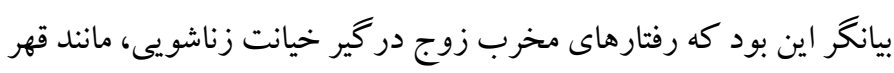

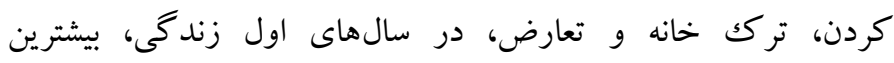

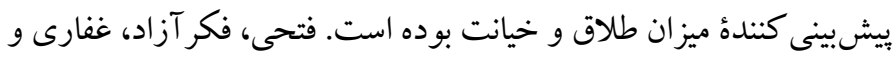

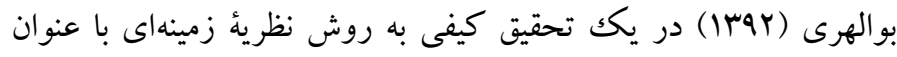

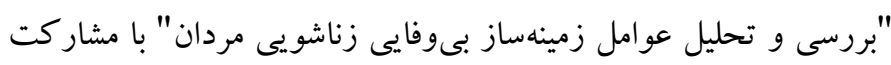

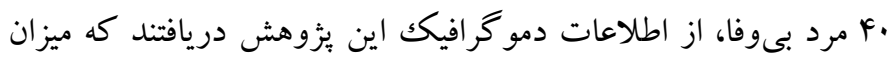
بى وفايى مردان، در مشاغلى كه ارتباط زيادى با جنس مخالف دارند، بيشتر است و بيشترين ميزان بىوفايى زناشويى در ده سال اول ازدواج آنها اتفاق

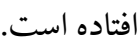
همانطور كه مشاهده مىشود، كمتر يُزوهشى به كشف علل زمينهساز و

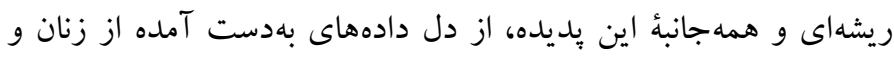

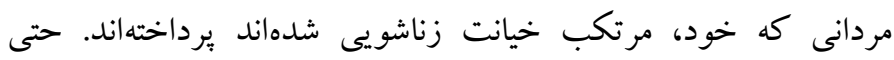

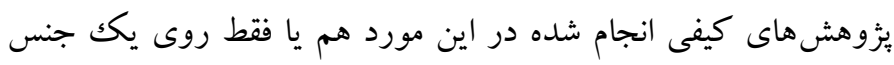

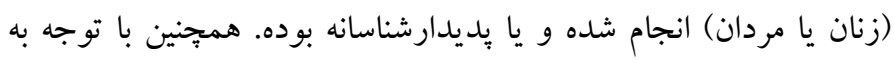

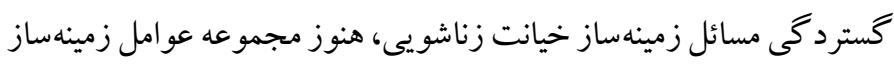

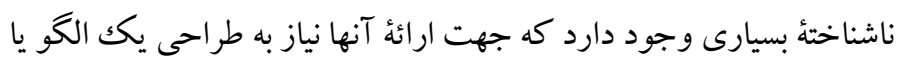

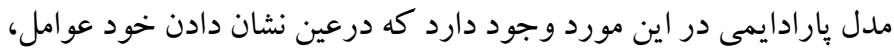

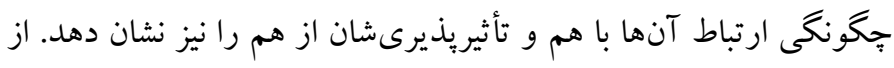

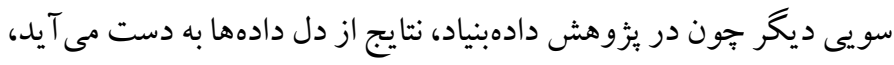

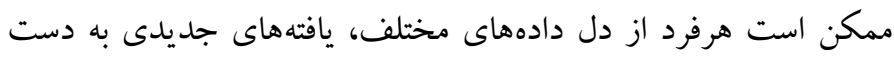

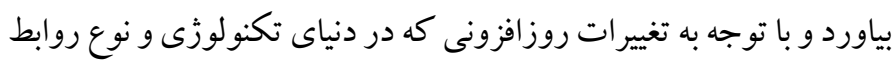

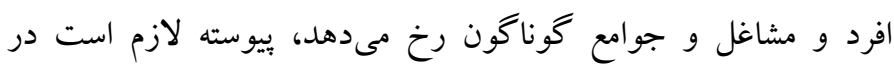
زمينههاى مختلف، يزوهش هايى مطابق با تغييرات روز انجام شود. همانطور

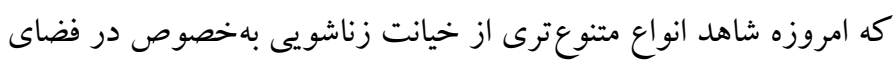
سايبرى هستيم كه در يزوهش هاى قبلى وجود نداشته. به گفتئه وايزر و و

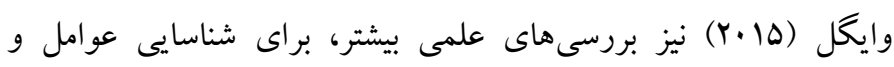

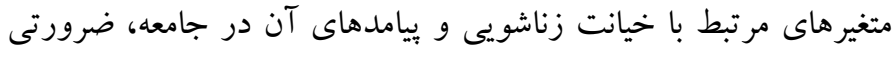
اجتنابنايذير است. بُزوهش حاضر نيز در جستجوى باسخ به اين سؤال

${ }^{1}$.Granded Theory 
رسيدن به اشباع دادهها كه \1 نفر بودند، ادامه يافت و يس از آن، جهت اطمينان بيشتر، با سه نفر ديخر نيز مصاحبه شدو تعداد مشار كت كنند كان به اب نفر رسيد تا در عمل، ييشرفت مطالعه به شناسايى مقوله يا مفهوم جديدى منجر نشود. جهت رعايت ملاحظات اخلاقى، ابتدا هدف تحقيق، رويههاى تحقيق، خطرات و فوايد تحقيق، ماهيت داوطلبانه بودن شركت در تحقيق، براى آنان بيان شد. حق شركت كننده براى انصراف از شركت در تحقيق در هر زمانى و روش هايى كه فرد را مورد محافظت قرار دهد، مد نظر قرار كرفت. به شركت كنند گان در يزٔوهش اطمينان داده شد كه اطلاعات بهدست آمده از آنها محرمانه خو اهد ماند و نتايج يزوهش، بدون ذكر نام آنها منتشر خو اهد شد. به منظور رعايت اين امر، در حين بيادهسازى نوارها، همه اسامى به كد، تغيير و طى تحليل دادهها و بيان نتايج نيز صرفا با همان كدها به آنها اشاره شد.

$$
\text { معيارهاى خروج عبارت بود از: }
$$

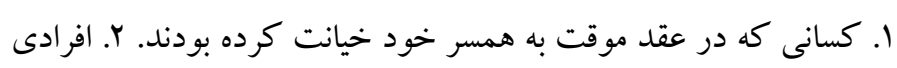

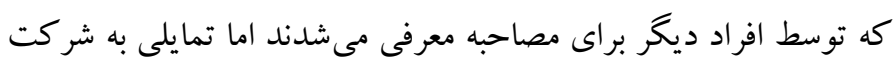
در مصاحبه نداشتند. جامعهُ مورد مطالعه، شامل تمامى مردان و زنانى بود كه در سالهاى 99 تا 99 به دليل در گيرى در خيانت زناشويى، به مراكز مشاورة استاد روزبه، راه نو، يرند و مهر آيين در تهران مراجعه نمودهاند. در اين يثزوهش براى انتخاب نمونه، از روش نمونه گيرى هدفمند استفاده

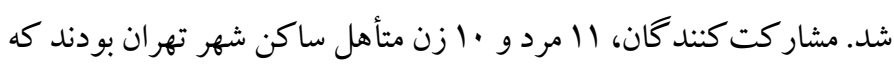
تجربه خيانت زناشويى داشتند و علاوه بر تمايل به شركت در مصاحبه، توانايى انتقال اطلاعات را هم داشتند. از آنجا كه در اين يزوهش، روش تعيين حجم نمونه، روش اشباع دادهها بود، فر آيند انتخاب آزمودنىها تا

جدول ا. ويثزكى هاى جمعيت شناختى افر اد شر كت كننده در ئوهش

سن س سن ازدواج

- نقش كيفيت رابطه با همسر، در شخل گيرى خيانت زناشويى در آن فرد

جه بود؟ - نكرش فرد به ازدواج به عنوان يكك تعهد تا جهه حد در گر ايش او به خيانت زناشويى نقش داشته؟ - نقش انتظارات فرد از همسرش، در كرايش به خيانت زناشويى او جه بوده؟ - آيا سابقه خيانت زناشويى در خانو اده يا اقوام درجه يكك فرد خيانت كار وجود داشته است؟ همجنين سعى شد در زمان اجراى مصاحبهها، شر كت كننده، هدايت اصلى روند مصاحبه باشد. طول مدت زمان هر مصاحبه، باز و مدت زمان اجراى مصاحبه ها بسته به مصاحبه شونده، از يكك تا سه ساعت به طول مى انجاميد. هر مشاركت كننده، بسته به ميز ان اطلاعاتى كه بيان مى كرد، بين دو تا سه جلسه مصاحبه داشت كليه مصاحبه ما با رضايت كامل مشاركت كند گان و بدون حضور افراد ديخر در مركز مشاوره مهر آيين انجام و در قالب يكك فايل صوتى ضبط مى گرديد. يس از اتمام مصاحبه، فايل صوتى روى كاغذ بياده مىشد تا مورد تجزيه و تحليل قرار كيرد و نتايج آن در فر آيند اجراى مصاحبه هاى بعدى لحاظ شود.
ب) ابز ار ابزار كرد آورى دادهها در اين يزٔوهش، مصاحبه عميق نيمهساختار يافته بود. ابتدا مصاحبهها با يكك سؤ ال كلى در مورد عامل يا عو امل كر ايش فرد به إنه سوى خيانت زناشويى آغاز مىشد و در طول مصاحبه در مواقع لازم از سؤالات كاوشخرانه، مانند: "مى توانيد در اين باره بيشتر توضيح دهيد؟ يا مىشود منظورتان را واضح تر بيان كنيد؟" جهت دستيابى به جزئيات و اطلاعات غنى تر استفاده شد. بس از انجام مصاحبههاى نخست، سؤالات ديخرى نيز به سؤالات آغازين اضافه شده و در مصاحبه إى بعدى مورد استفاده قرار مى گرفت. به عبارت ديخر يس از تحليل اولين مصاحبه، اين سؤالات و مفاهيم، جاى خود را به مفاهيمى مىدادند كه از دادهها استخراج مىشدند. بنابراين، سؤالات اوليه، مبناى گردآورى دادهها در مصاحبههاى بعدى مى شدند. يس از يِادهسازى و تجزيه تحليل و كد كذارى هر مصاحبه، سؤالاتى به سؤالات مصاحبهى بعدى جهت دريافت كدهاى جديد، افزوده مىشد. سؤالات اساسى كه از ابتدا و در مصاحبه ساى آغازين راهنماى يزوهشخر بودند، عبارت بود از: - خيانت زناشويى جه جذابيت هايى براى آنان داشت؟ - ابتدا جهه جِيز فرد را به آن سمت سوق داد؟ 
ييشفرض هاى بيشين خود را تا حد امكان در فرايند جمع آورى اطلاعات دخالت ندهد. r) جهت تضمين قابليت اطمينان و كفايت، از راهنمايى متخصصان در زمينه كيفى استفاده شد. \&) جهت افزايش قابليت انتقال، از حضور هر دو جنس استفاده شد. براى بررسى اعتبار اين بثزوهش، بثزوهشكر در طول مصاحبه و ييادهسازى و

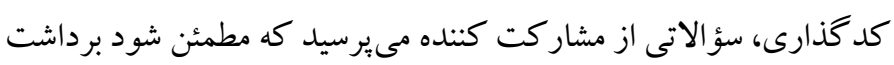

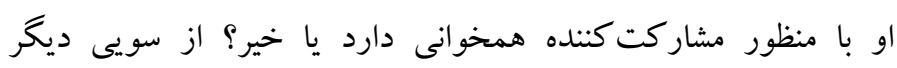
يزٔوهشكر، جهت بررسى وجود سو گيرى شخصى، با همكاران خود به بحث در مورد يافته هاى خود يرداخته است. در ادامه نيز جهت كسب بيشترين اجماع، نظر متخصصان تحقيق كيفى را نيز در مورد كدها، جويا شده است. نتايج حاصل از تجزيه تحليل دادهها در جدول ا ارائه شده است. إفتهن تجزيه و تحليل دادهها با استفاده از آزمون تحليل كوواريانس جند متغيرى و نرمافزار SPSS نسخه سץ صورت گرفت. در ابتدا يافتههاى توصيفى يثزوهش با استفاده از آمارههاى ميانكين و انحر اف معيار گز ارش مى گرددد، سيس يافته هاى استنباطى و آزمون فرضيهها مطرح مىشوند. ميانخين و انحراف معيار متغير خودكارآمدى اجتماعى و زير مقياسهاى آن در دانش آموزان تيزهوش در مرحله ييش آزمون و يس آزمون در جدول ب ارائه
روش تجزيه و تحليل دادهها: براى تحليل دادهها از روش سه مرحلهاى كد گذارى و مقايسٔ مداوم ييشنهاد شدهُ اشتراس و كربين ( • 199) استفاده شد. به اين صورت كه ابتدا يس از يياده كردن مصاحبه ها، در مرحله كد كذارى باز، متن مصاحبه به بخشهاى مختلف خرد مىشد. سيس جملات يا ياراگر اف هاى مفهومساز به عنوان كدهاى اوليه يا كدهاى خام استخراج مىشدند. يس از آن به جمله يا ياراكر افهاى استخراجشده بر اساس محتواى آن، يكك بر جسب داده مى شد كه همان كد ثانويه بود. در مرحلة بعد با مقايسٔ مداوم كدها با يكديگر و با ديخر دادههاى بدست آمده از مصاحبهها، به طبقهبندى دستههاى موضوعى فرعى و طبقات، بر مبناى ويز كى هاى مشابه، وجوه مشتر كك و تناسب ميان مقولات يرداخته شد. در اين مرحله، با استفاده از كد كذارى محورى، رابطهُ موجود درون خوشه ها، و روابط ميان طبقات فرعى با دستههاى موضوعى، تعيين و يردازش كرديد. با رسيدن به مرحلهُ اشباع دادهها، كلئ مقولهها و طبقات، با بهره كيرى از كدگذارى انتخابى، يكڤارجه سازى و تر كيب شدند. به منظور صحت و اعتباريابى دادههاى يزوهش، از جهارشاخص موثق بودن اعتبار گوبا و

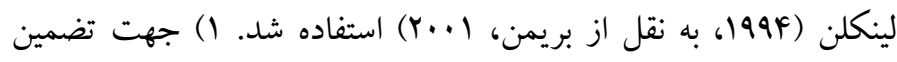
قابليت اعتبار دادهها يّ از تحليل، هر مصاحبه دوباره به شركت كننده باز خشت داده شد و صحت و سقم مطالب، تأييد و تغييرات لازم اعمال كرديد. Y) جهت تضمين قابليت تصديق، سعى شد كه يزوهشخر،

جدول r. عوامل اصلى مفاهيم مقولات و طبقات تأثير تذار در كر ايش به خيانت زناشويى

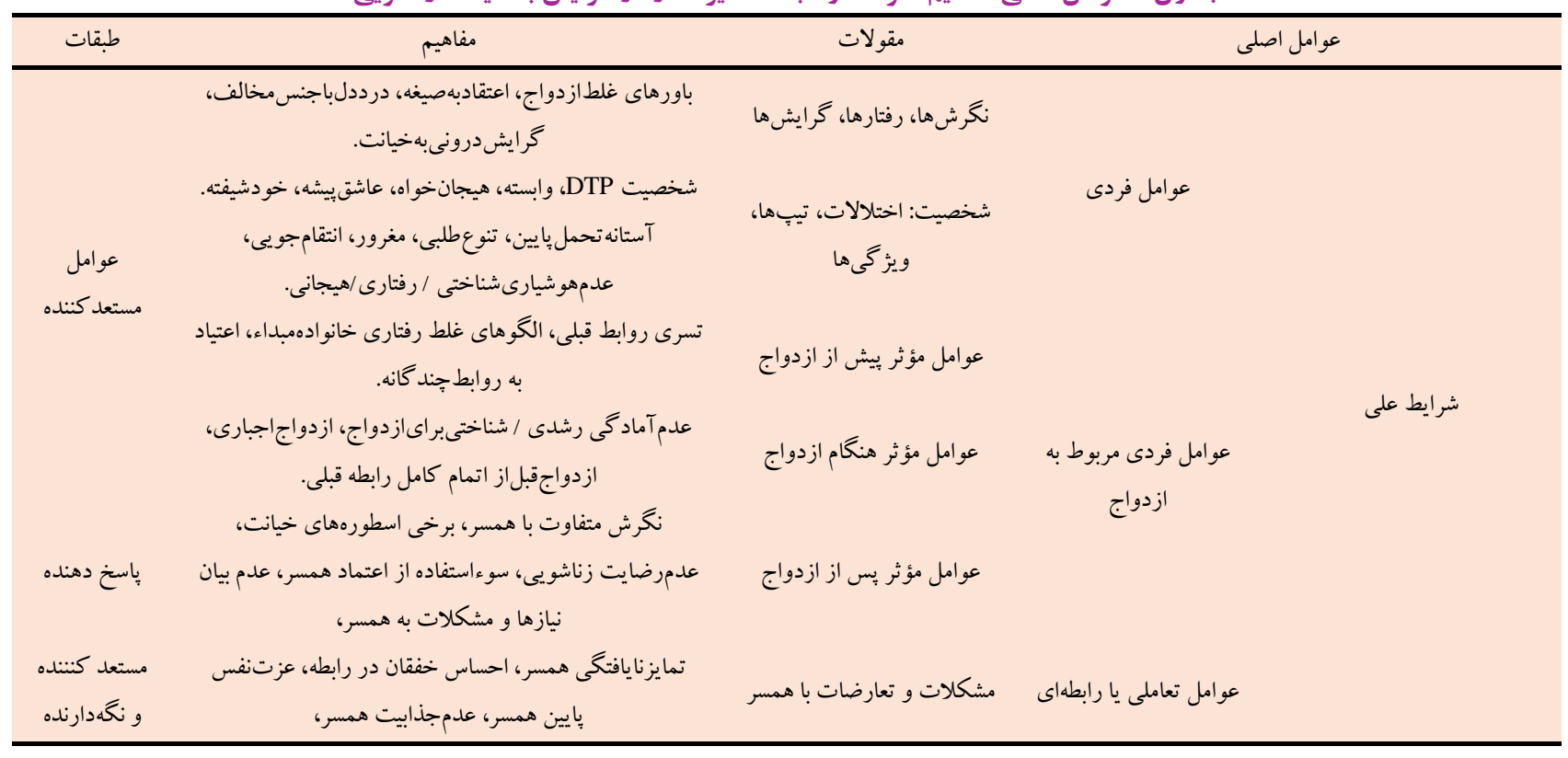




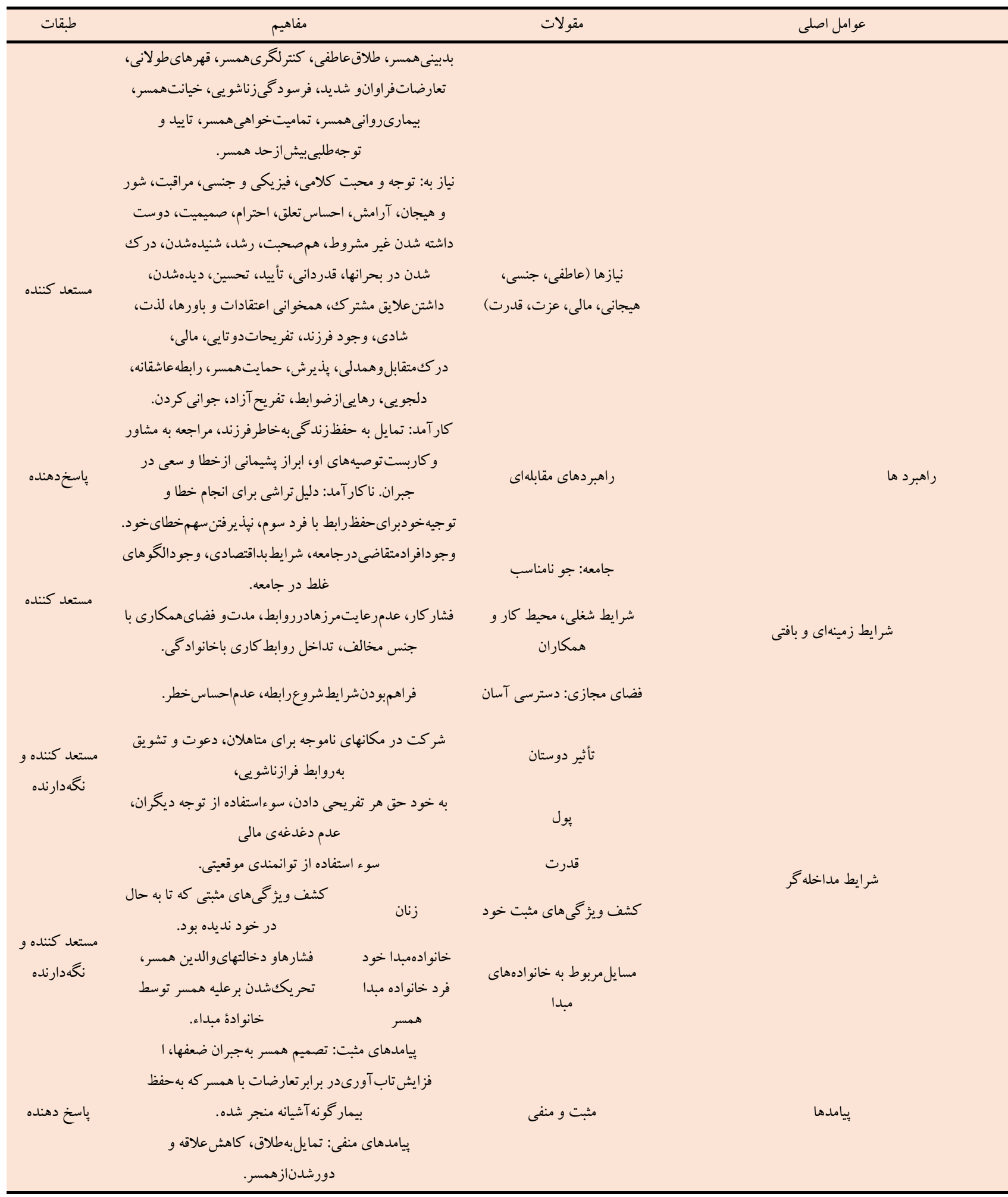

"وقتى بيينى هيج كدوم از نيازهات با همسرت برآورده نمىشه، جى كار در زير نمونهاى از بيانات مصاحبهشوند كان روايت گرديده است.

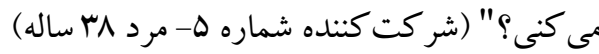
مقوله محورى (نيازها) 
بس از ازدواج (تعارضات زناشويى)

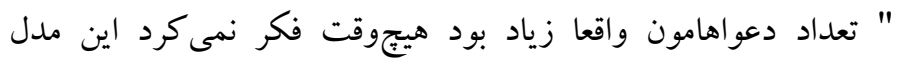

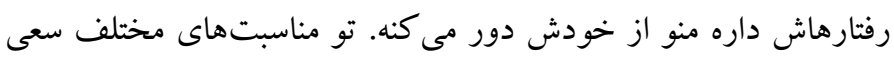
كردم رابطمون رو گرم كنم. اما اون نمى خواست." (شر كت كننده شماره

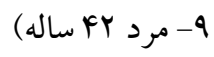
"من يادمه هميشه قهرامون يه هفته، دو هفته يا سه هفته بود. يه بار يادمه

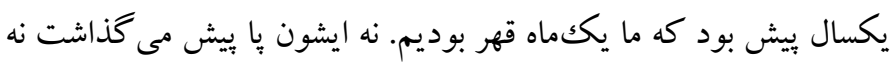
من. " (شركت كننده شماره q- زن سF ساله) شرايط مداخله كشف ويز گیى هاى مثبت خود "اون دخترخانم تو اداره، عاشق منه. بر اى من خيلى ارزش قايله و وبهم احترام

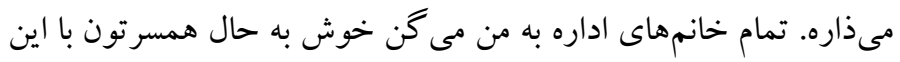

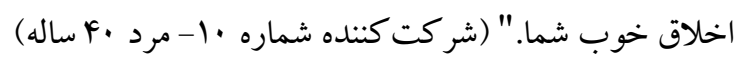

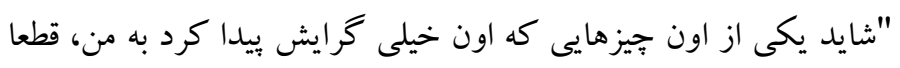
قوى بودن من توى كار بودو زن خودش اين مدلى نبود. قوى بودن من، تو تو توني

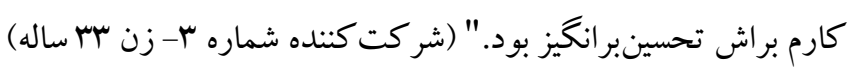
يول و قدرت

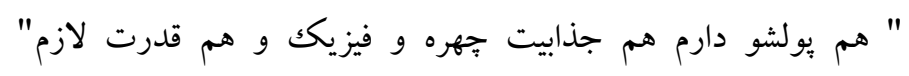
(شر كت كننده شماره ا-مرد اس ساله)

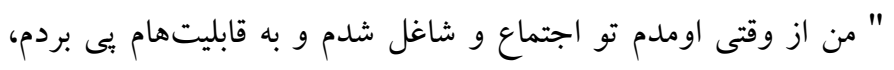

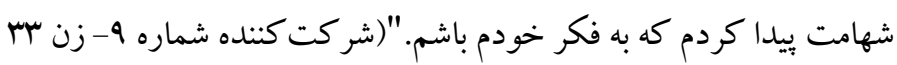

ساله) باورها و عقايد "من از همون اول حق خودم مىدونستم هميشه هم حق خودم مى حونم. جيزيه كه در دين ما هست و من بهش اعتقاد دارم و صيغه كردن رو اصن اصلا خيانت نمىدونم."(شر كت كننده شماره r - مرد . ب ساله) تأثير دوستان "وقتى با دوستام دور هم جمع مىشيم همه با افتخار از خيانتهاشون

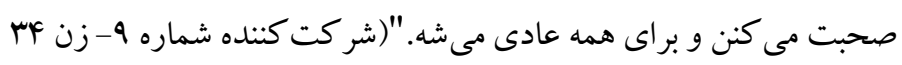
ساله) " دوستام اهل زن و صيغه و اينا بودن ولى من نه." (شر كت كننده شماره 9مرد باله
" من به دنبال يك نياز، نياز به دوست داشته شدن بىقيد و شرط و بدون توقع بودم." (شر كت كننده شماره ا- مرد اسب ساله) شرايط على (عوامل شخصيتى) شخصيت سه گانهُ اهريمنى (خودشيفته، ماكياول و جامعهستيز ) " من اين كار (صيغه) رو حق خودم مىدونستم. دوست داشتم تفريح كنم.

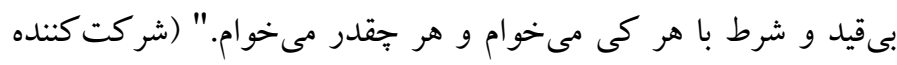
شماره r- مرد ·r ساله) شخصيت وابسته "خيلى بهش وابسته شده بودم. بدون اون زندگى برام خيلى غير قابل تحمل

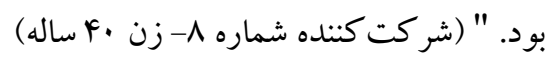
" خيلى بهش وابسته شدم و برام سخته دورى ازش." (شر كت كننده شماره r- مرد ·r ساله) شر ايط على (ويز گیى هاى فردى) نخرش فرد به ازدواج " جون دو دفعه ازدواج كردم بايد يه كسى باشه كه منو دوست داشته باشه آنه و با شرايطم كنار بياد." (شر كت كننده شماره ه- مرد ^ب ساله)

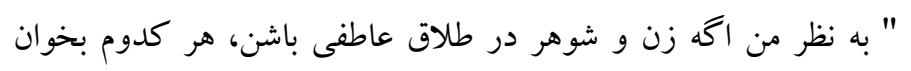

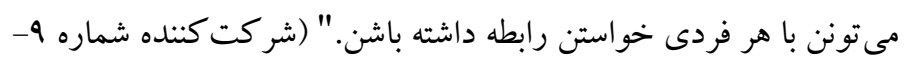

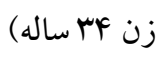
شرايط على (عوامل فردى مربوط به ازدواج) بيش از ازدواج (تسرى روابط قبل از ازدواج)

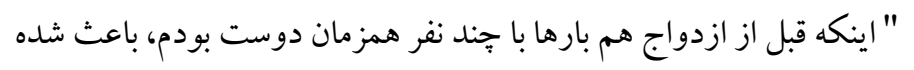

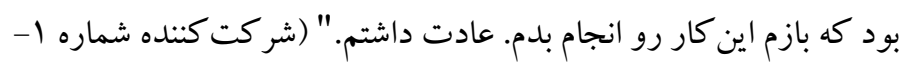
مرد اس ساله) هنغام ازدواج

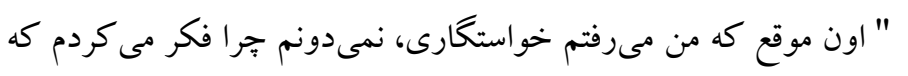

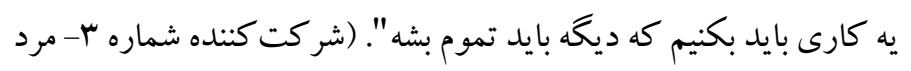
(d) " يكك ازدواج سنتى بود. فقط به خاطر بدرم بله گفتم."(شركت كننده

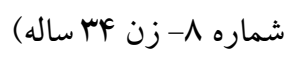


" من از اون رهنمود شما در جلسه مشاوره خيلى استفاده كردم و همين خيلى در تركى اين روابط و حفظ زندكيم به من كمك كرد. "شركت

كننده شماره A- مرد F س ساله) نا كار آمد نيذيرفتن سهم خطاى خود " مى گم ما هيج مشكلى با هم نداشتيم كه بحم كه يه مشكلى داريم يه بديى مى كنه، كار بد مى كنه. نهرهه.. اين آدم فقط بيماره. " (شر كت كننده شماره

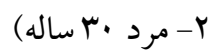
" از بس منو اذيت مى كرد و كتكك مىزد با اون آقا دوست شدم كه فقط مرد صحبت كنيم. تازه باعث افسردكى منم، خودش شد." (شركت كننده شماره ه- زن مب ساله) يافتن راههاى جديد بنهان كارى " به حساب خودم فكر مى كردم مى كفتم اتفاقى نمى افته فقط به من كير مىده و من يه راهكار ديخه يه سوراخ زيرزمينى ديكه بيدا مى كنم.

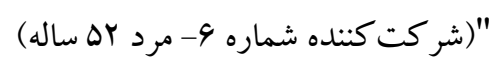
" به عنوان مأموريت كارى، دنبالش رفتم خارج از كشور. "(شركت كننده

$$
\begin{aligned}
& \text { شماره زن ها ساله) } \\
& \text { بيامدها } \\
& \text { مضر يا منفى }
\end{aligned}
$$

دور شدن از همسر و تمايل به طلاق " بودن اين خانوم خيلى مصممترم كرده بود براى اينكه از همسرم جدا بشم." (شركت كننده شماره r- مرد له ساله) "وقتى اون رابطه با تلخى تمام شد، بعد از V يا Nماه، من خودم به اين نتيجه رسيدم كه اين زندكى ديگه فايدهاى نداره. جون نيازهاى تو اينجا بر آورده نمى شه. يس بهتره كه ديخه جداشى."(شر كت كننده شماره ا زن هب ساله) عدم تلاش براى ترميم رابطه با همسر "من ديخه اصلا نمى خواستم هيج تلاشى كنم با شوهرم براى بهبود

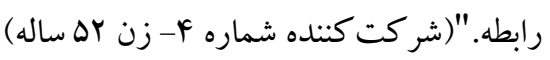
" من مىدونم كه رابطه من با همسرم هيجوقت درست نمىشه براى همين نمى خو ام تلاشى در اين زمينه بكنم."(شر كت كننده شماره 9-زن ع ساله) بيامدهاى مفيد يا مثبت
شر ايط زمينهاى (بافت) شر ايط شغلى " تو اون شرايط بحر ان ادارى، نياز به يكك هميار كه به رييس اداره نزديك باشه داشتم كه اين خانوم بود."(شر كت كننده شماره ||- مردساله ^ץ) عدم وجود مرزها در محل كار و روابط كارى " ما تو محل كار، بهم خيلى نزديك شده بوديم. اون منو خيلى قبول داشت و از من تعريف مى كرد. در حالى كه همسرم منو مسخره مى كرد."

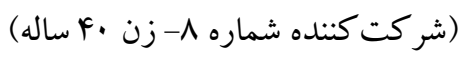
" تو اداره، روابط همكاران جنس مخالف با هم خيلى صميمى شده بود. ساعات طولانى با هم كار كردن تو يكك اتاق. متأسفانه مرزهاى ارتباطى رو رعايت نكرديم." (شر كت كننده شماره ||- مرد رب ساله)

جامعه اوضاع نابسامان اقتصادى در جامعه "من يه كارگرم حقوقم ماهى دو ميليونه، به خواهرم بدهكار بودم مجبور شدم طلاهاى خانمم رو بفروشم تا بدهىام به خواهرم رو بدم. زنم همش سر اين موضوع به من غر مىزد." (شر كت كننده شماره ا- مرد اس ساله) وجود الكوهاى غلط در جامعه يا خانواده و اقوام "شايد علت زياد شدن خيانت اينه كه خيلى راحت خانمها بر اى هم تعريف مى كنن و افتخار هم مى كنن." (شر كت كننده شماره 9- زن Fr ساله) "ديخه الان همه مرداى متأهل، دوست دختر دارن. تو ادارات همهى مديران "جند تا دوست دختردارن". (شركت كننده شماره 9- مرد، ه هاله) فضاى مجازى

"من با اين آقا تو فيس بوكك آشنا شدم." (شركت كننده شماره V- زن) " به عنوان مدرس، تو شبكهاى مجازى عضو بودم. و از اون طريق خانمهايى كه متقاضى كلاس بودن با من در ارتباط بودند." (شركت كننده

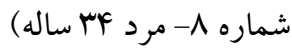
راهبردها

كار آمد (كاربست توصيههاى مشاور براى ترميم رابطه، رعايت مرزها) " كم كم وقتى ديدم از من انتظارات ديخرى (رابطه جنسى) داره رابطهام رو قطع كردم."(شركت كننده شماره F- زن F اله ساله) 
تلاشم رو مى كنم تا نيازهاشو برطرف كنم." (همسر شر كت كننده شماره F

تحمل بهتر تعارضات

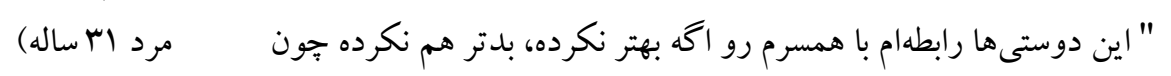
"من ديخه تمام تلاشم رو دارم مى كنم كه اون راضى باشه. ديگه بهش

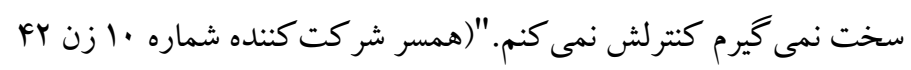

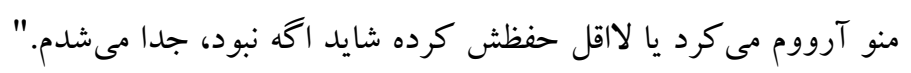
(شر كت كننده شماره (- مرد ب س ساله) ساله) جدى تر شدن همسر بر ایى رفع نيازهاى فرد

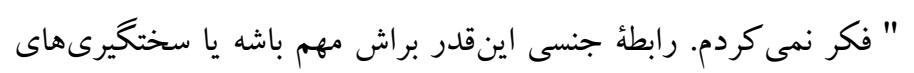

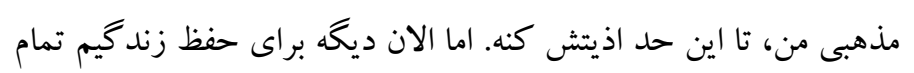
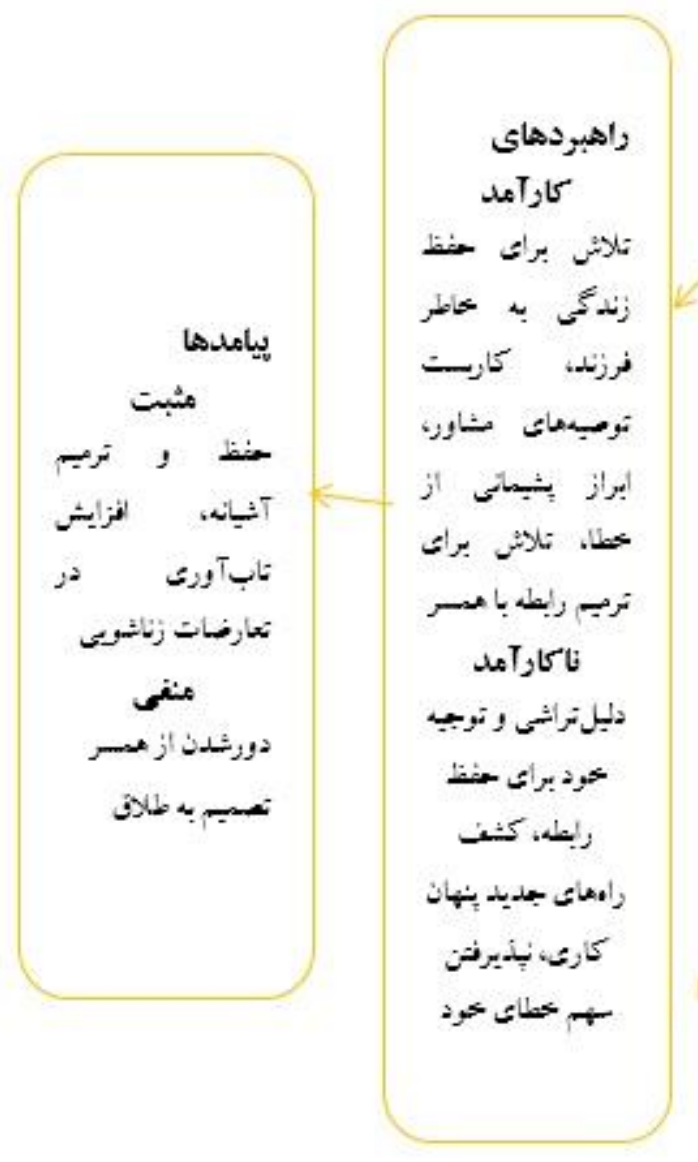

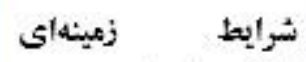
(بافتارى) جامعه (مسائزل

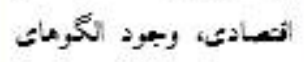
غلط) شغل (تشرايطكارن مرزعاث أرتباطى، جمايكا.

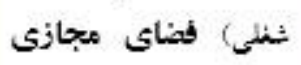
(تسهل ارتباط، تسيل فئل بهاذ حاندن ارتباط). شرانيط

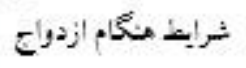
فردى - شخصيتى وبرئي $-1$ زوجم - رابطداى تعارغات زنثئويى

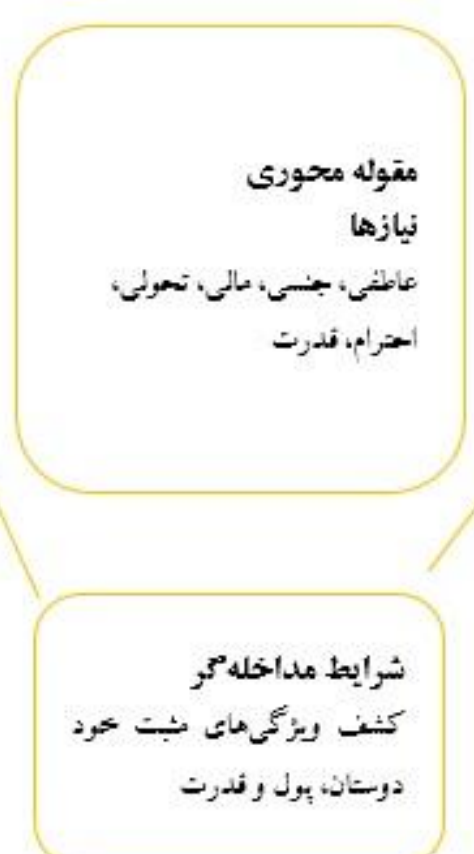


رابطهاى، شرايط زمينهاى و بافتارى و تأثير محيط و بافت فرهنكى -

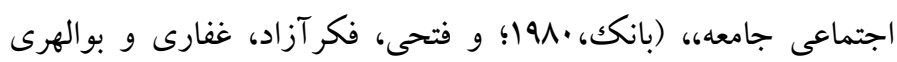

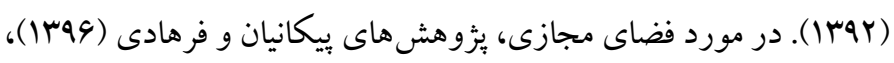

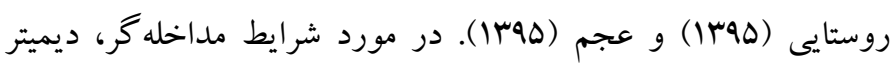

بر اساس نتايج حاصل از اين يُزوهش و هماهنگى برخى از نتايج اين

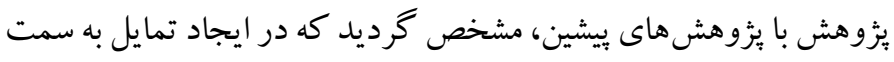

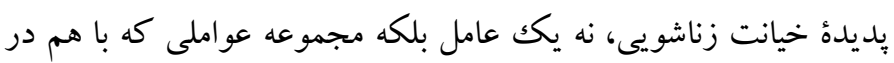

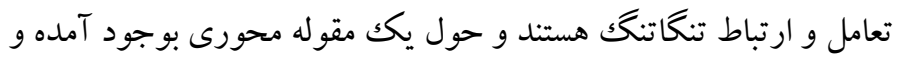
در همان راستا عمل مى كنند؛ نقش دارند. در تمام مصاحبههاى اين يُوهش، مشخص گرديد افر ادى كه مرتكب خيانت زناشويى شده بودند، همه به نوعى بهدنبال رفع يكك نياز، حتى بيمار گونه بودند. اكثر آنان، آشكارا

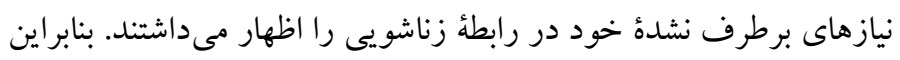

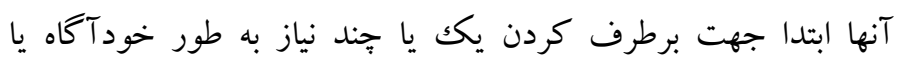

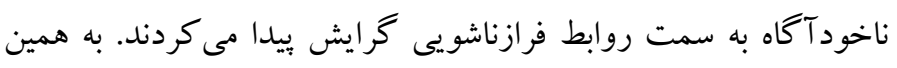

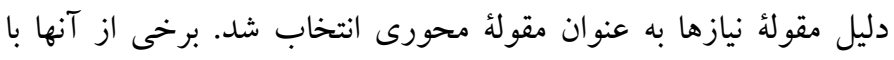

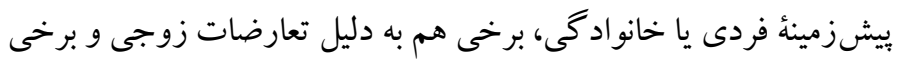

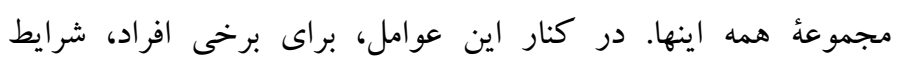

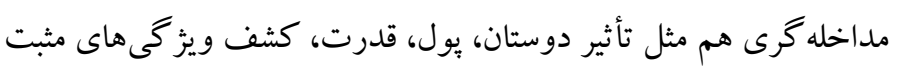

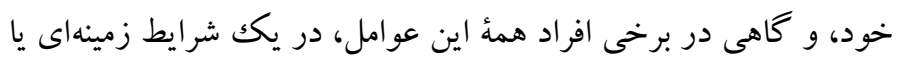

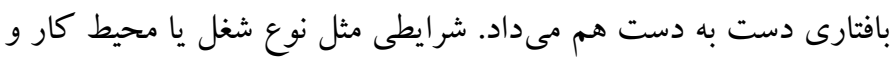
شيوه ارتباط همكاران، فضاى مجازى، وجود الكوهاى غلط در جامعه و

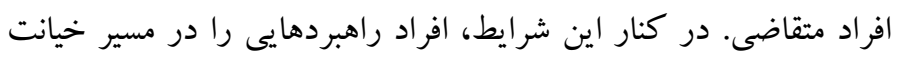

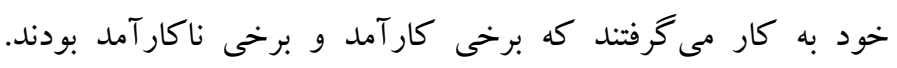

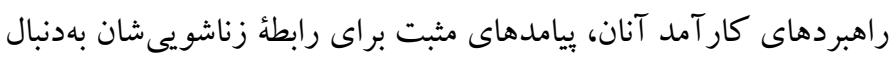
داشت و راهبردهاى ناكار آمدشان منجربه بيامدهاى منفى و آسيبزننده به

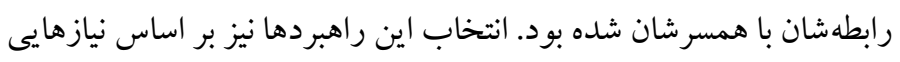

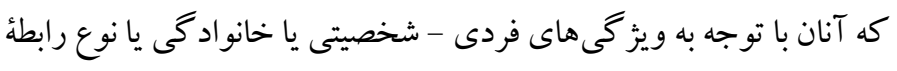
زوجى خود داشتند؛ در بستر شرايط زمينهاى مربوط به هرفرد و شرايط

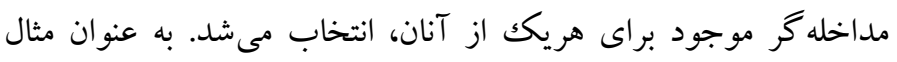

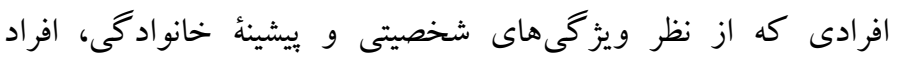
متعهدترى بودند، به حفظ رابطهُ زناشويى و خانو ادهٔ خود بيشتر از حفظ يك ونى
جمع بندى خلاصه از بيانات مشار كت كنند گان: همانطور كه با ذكر تعدادى

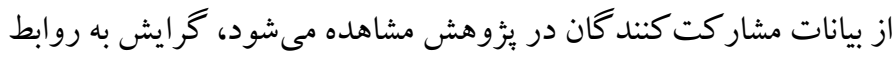
فرازناشويى در افراد مختلف، از تعامل مجموعه عوامل متعددى تأثير

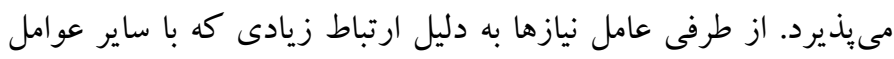

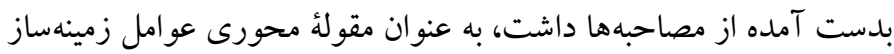

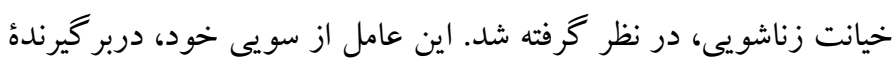

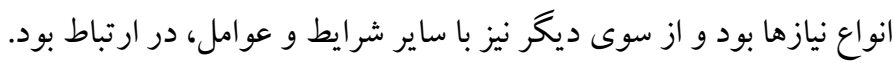

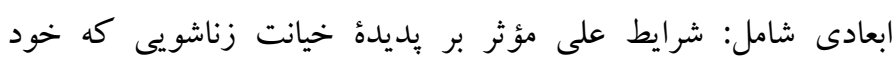

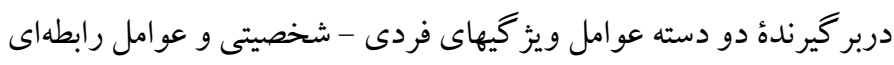

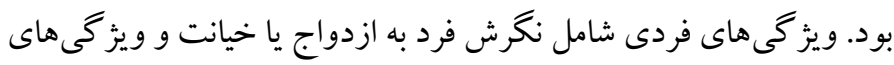

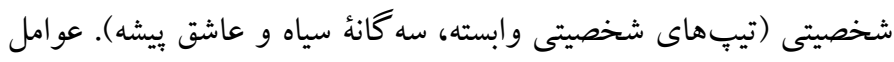

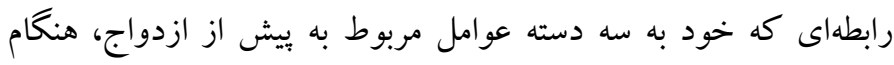

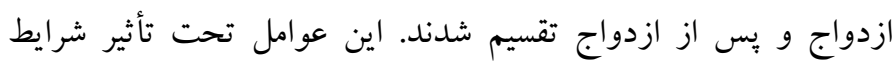
مداخله گرى مثل كشف ويز گىهاى مثبت خود، تأثير دوستان، يول و و

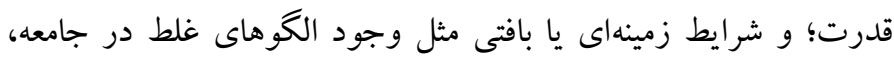
شرايط شغلى، عدم رعايت مرزهاى ارتباطى در محل كار، اوضاع نابسامان ونسان اقتصادى و وجود فضاى مجازى كه خود باعث سهولت دستر سى مى شو دي؛

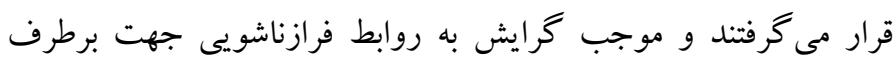

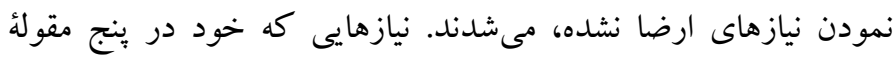

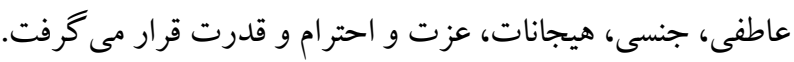

\section{بحث و نتيجه تيرى} هدف از انجام اين يُزوهش، شناسايى عوامل زمينهساز گرايش به خيانت

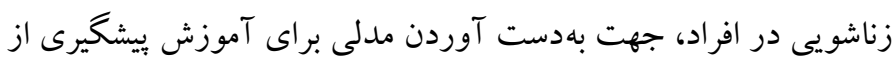

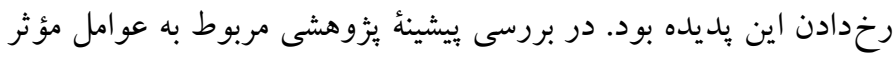

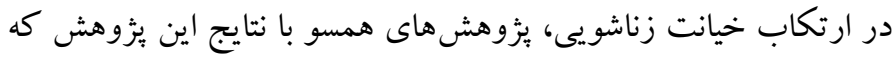

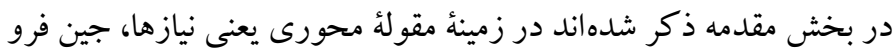

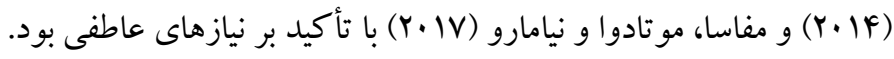

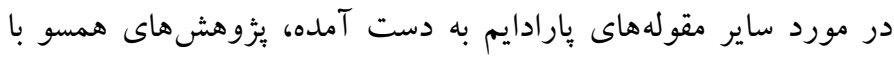

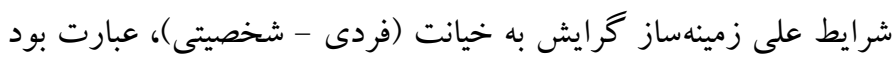

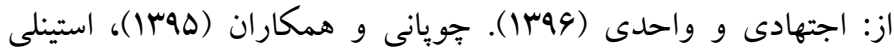

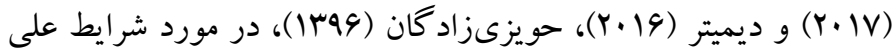


نيز ييشنهاد مى شود كه در جلسات مشاوره بيش از ازدواج خود، به عوامل

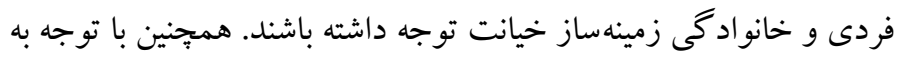

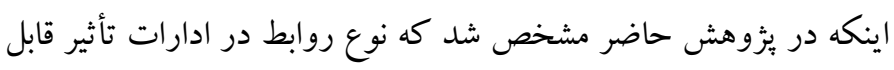

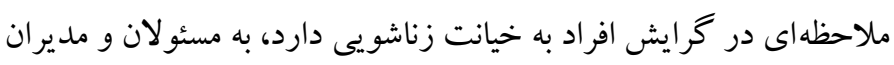

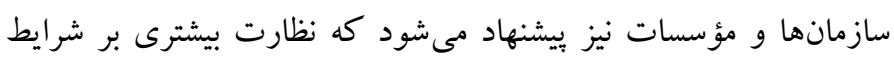

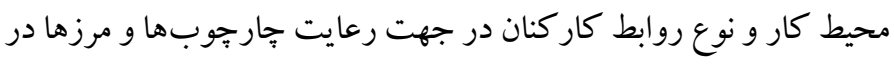

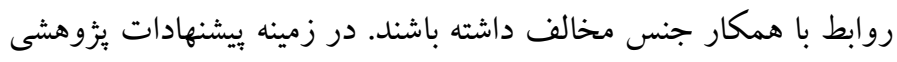

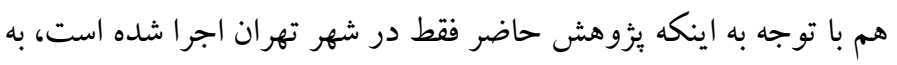

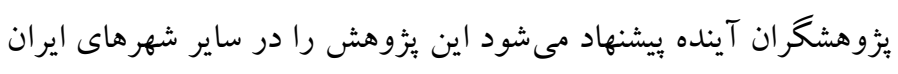

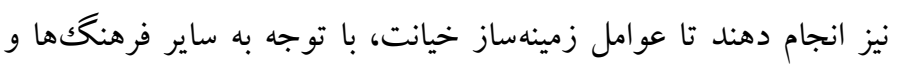

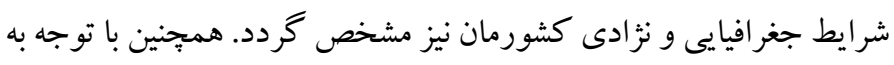

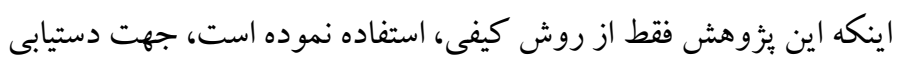
به اطلاعات دقيق تر، انجام يثزوهش آميخته (كيفى - كمى) در اين زمينه به رونه

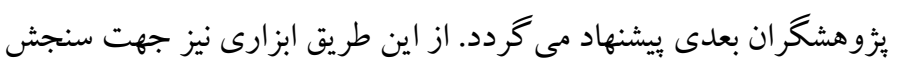

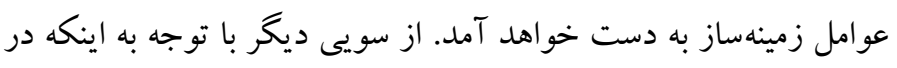
يزوهش حاضر، عوامل مؤثر برانواع خيانت به طور كلى مورد برسى قرار

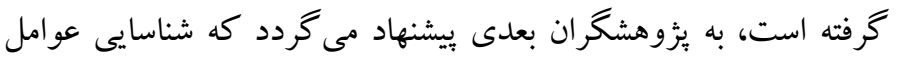

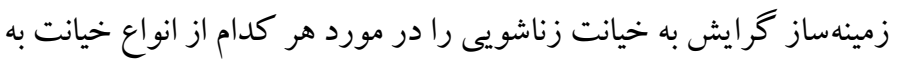

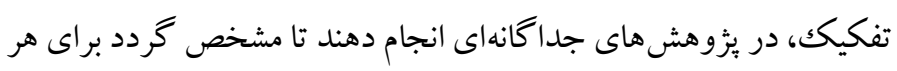

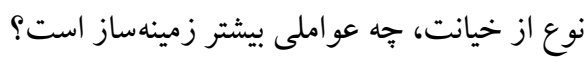

\section{ملاحضات اخلاقى} بيروى از اصول اخلاق ثئوهش: اين مقاله بركرفته از باياننامه نويسنده اول ا ست.

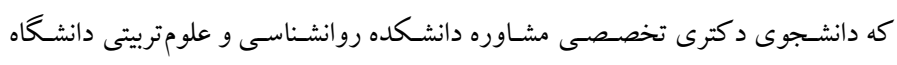

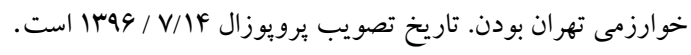

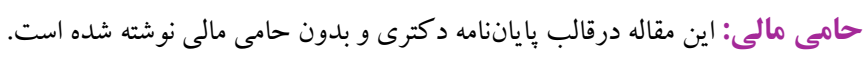

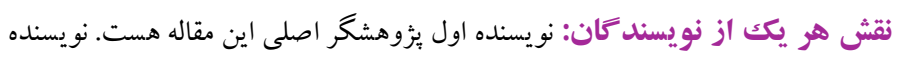
دوم استاد راهنما و نو يسنده سوم استاد مشاور بِاياننامه هست.

تضاد منافع: نويسند گان هيج تضاد منافعى در رابطه با اين يثوهش اعلام نمى نمايند.

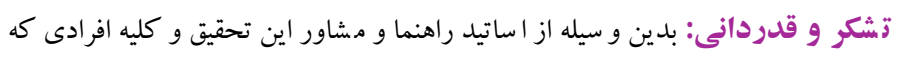

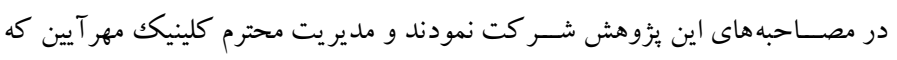
فضاى مناسبى جهت انجام مصاحبه ها فراهم نمودند، تشكر و قدردانى مى شود.
رابطة فرازناشويى، نياز داشتند. بنابراين راهبردهاى كار آمدى مثل تلاش براى ترميم رابطه با همسر و يذيرفتن سهم خطاى خود و واستفاده از

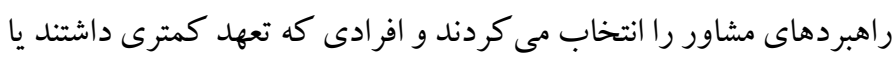

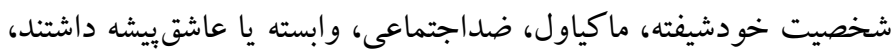

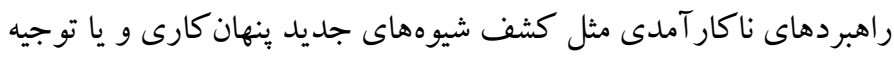

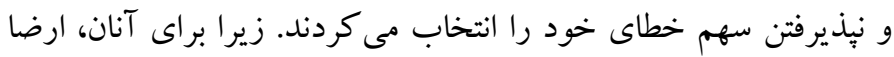

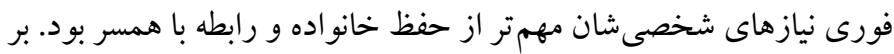

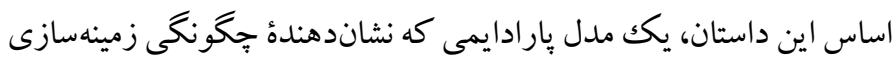

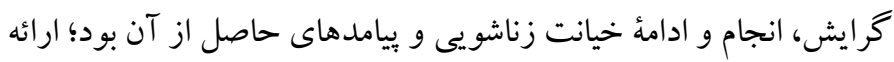

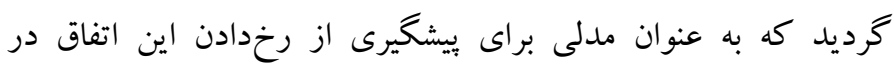

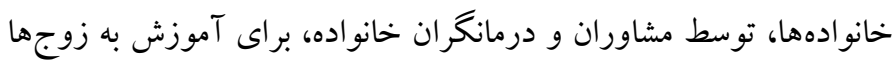

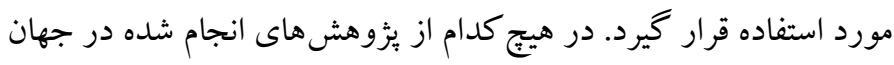

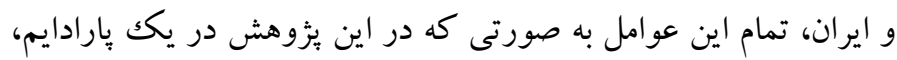

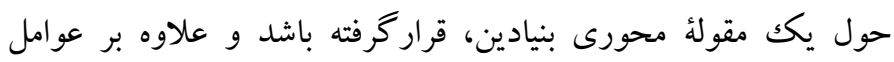
زمينه ساز به عوامل تداوم دهنده و باسخدهنده نيز اشاره كرده باشد، مشاهده نشد. محدوديت اين يثزوهش در زمينه كرد آورى دادهها بود. جون با وجود آنكه

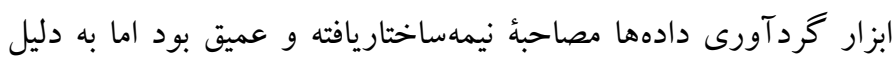

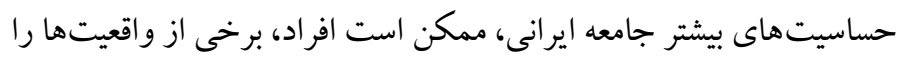

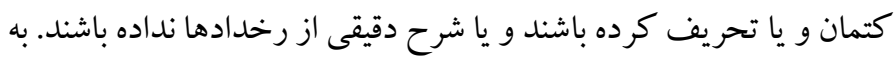
خصوص زنان به دليل سختخيرى بيشترى كه در زمينه خيانت زناشويى در

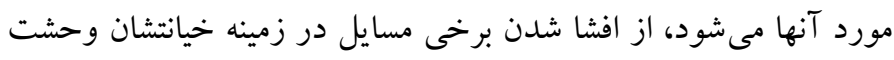

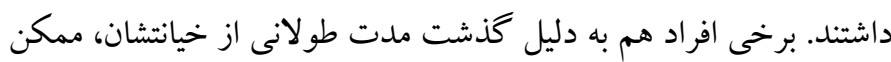

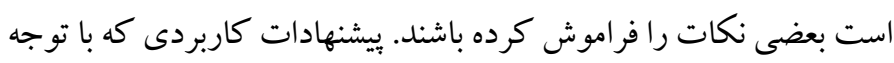

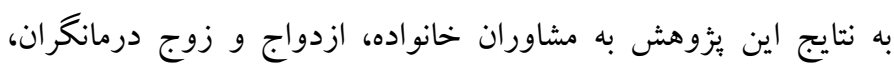

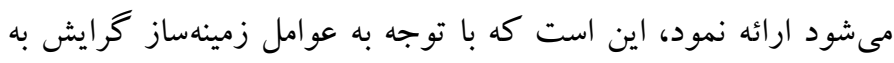

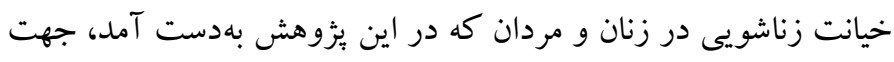
بيشخيرى از رخدادن خيانت در زوجها، برنامههاى آموزشى جهت دون واكسينه كردن روابط زوج در اين زمينه براى قبل از ازدواج افراد و همجنين

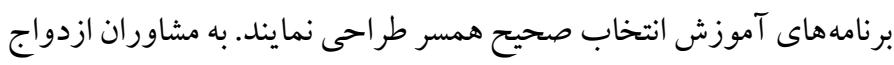




\section{References}

Ejtihadi, M, Vahedi, G. (2017). Sociological study of the potential of infidelity in marital relationships and the factors affecting it. Sociology of Iran, 17 (4), 105-138. [Link]

Afshari Kashanian, O., Zahrakar, K. Mohsenzadeh, F., Tajik Ismaili, A. (2018). Identifying the underlying factors of marital infidelity in women. Consulting Research, 18 (71), 122 - 156. [Link]

Peykanian, R.,Farhadi, H. (2017). Investigation of Internet addiction, the use of online media messages and Internet infidelity as a precondition for divorce in couples on the verge of divorce and divorced in Isfahan. Cognitive Sciences, 7 (1), 81 - 87. [Link]

Choopani. M., Karami, M., (2016). Investigation of psychosocial injuries based on family life cycle. Research project, Imam Hossein University, Tehran. [Link]

Haviziazadegan, N., (2016). The relationship between emotion seeking, positive and negative emotions, and emotional resentment with marital infidelity. Master Thesis. University of Kermanshah. [Link]

Rustaei, M. (2016). Investigating the effect of emerging media (Internet, satellite and mobile phones) on emotional infidelity of couples and the factors affecting it. Journal of Principles of Mental Health, Special Issue of the Third International Conference on Psychology and Educational Sciences, 23-419. [Link]

Ajam, A., (12016). The effect of direct and indirect satellite trainings on marital conflict and attitudes toward marital infidelity. Islamic Studies and Psychology, 10 (18), 125-146. [Link]

Fathi, M.; Fekrazad,H., Ghaffari, Gh.,Boalhari, Jafar (2013). Identifying the underlying factors of male marital infidelity. Social Welfare Research Quarterly, 13 (51), 131-109. [Link]

Kargar, M; Kimiaei, A.; Mashhadi, Al (2014). The effectiveness of couple therapy based on selfregulation, emotional harassment and marital turmoil. Journal of Family Counseling and Psychotherapy, 4 (2), 297-269. [Link]

Kalhor, S.; Sadeghi Fasaei, S. (2008). The dimensions of the gender gap and the extent to which it is reduced in the Third Development Plan. Women in Development and Politics, Fall '86, No. 2, consecutive 18,1 (5). 28-5. [Link]

Allen, E. S. Atkins, D. C. (2005), The multidimensional and developmental nature of infidelity: Practical applications. Jornal of Clinical Psychology, 61:1371-1382. [Link]

Allendorf, K., \& Ghimire, D. J. (2013). Determinants of marital quality in an arranged marriage society. Social Science Research, 42(1), 59-70 [Link]

Baranoladi, S., Etemadi, O., Ahmadi, S. A., \& Fatehizade, M. (2016). Qualitative evaluation of men vulnerability to extramarital relations. Asian Sosial Science, 12(7), 202-212. [Link]

Demeter, E., (2016). The effects of infidelity on couples from a therapeutic point of view. Individual Cabinet, Arad, 123-133. [Link]

Fisher, T. D. (2007). Sex of experimenter and social norm effects on reports of sexual behavior in young men and women. Archives Of Sexual Behavior, 36, 89100. [Link]

Jeanfreau, M. M., Jurich, A. P., \& Mong, M. D. (2014). An examination of potential attractions of women's marital infidelity. The American Journal of Family Therapy, 42(1), 14-28. [Link]

Hertlein, K. M., Wetchler, J. L., \& Piercy, F. P. (2005). Infidelity: An overview. Journal of Couple \& Relationship Therapy, 4(2-3), 5-1 [Link]

Loudova, Irena, Janis, Kamil, Jiri Haviger,. (2013). Infidelity as a threatening factor to the exsistence of the family procedia: Social Behavioral Sciences, 106(2013)1462-1469. [Link]

Maphosa, S., Mutandwa, P., \& Nyamayaro, A. T. (2017). Infidelity appetite: psychological factors influencing married women to engage in extramarital affairs. Int J Innov Res Dev, 6(1), 46-52. [Link]

Stinley, C. M. (2017). Exploring men's motivations and restraints in repeated extramarital sex. (A Master's Thesis in science counseling, College of Missouri State University. [Link]

Weiser, Dana A. Weigel, Daniel J. Weigel. (2015). Investing experiences of the infidelity partner: Who is the "Other Man/Woman"? Personality and Individual Differences, 85(2015)176-181. [Link]

Wimalasena, N. A. (2016). An analytical study of definitions of the term "Marriage". International Journal of Humanities and Social Science, 6, 166174. [Link] 